\title{
EFFECTIVENESS OF APPLYING NATURAL SOIL CONDITIONERS UNDER MOISTURE REGIMES ON SANDY SOIL PROPERTIES AND CEREAL CROPS PRODUCTION El-Kammah,M.A.M ${ }^{1}$; Marwa, G. M. Ali $^{2}$; M.A.Aboelsoud ${ }^{2}$ and
} S. A. Mashalli ${ }^{1}$

1-Soils and Water Sci. Dept., Fac. of Agric .,Kafrelsheikh Univ.,Kafr ElSheikh, Egypt

2-Soils, Water and Environ. Res. Inst., Sakha Agric. Res. Station, Egypt

ABSTRACT

Two experimental sites of arable sandy soil located at Abou Omera AlSharkeya village, Baltim district, Kafr El-Sheikh Governorate were chosen. The selected locations represent the conditions of circumstances of northern part of Nile Delta region. Site 1 ( fruit field) was devoted for collecting composite surface soil sample for carrying out wheat pot experiment in plastic pots during the growing winter season period 2010/2011. Site 2 (nearby site 1) was occupied for conducting maize field experiment during growing summer season period 2011. The main objectives of this investigation were to study and evaluate the effect of natural raw minerals, soil conditioner types, their mixtures and application rates in sandy soil subjected to different irrigation deficits on the following parameters: ( $i$ ) soil properties( chemical, physical, moisture constants and nutritional status after cereal crops harvesting and ( ii ) agronomical production of wheat and maize crops after full maturity in the studied soil under consideration.

Four types of soil conditioners [bentonite, compost, mixture of natural mineral raw materials (MNRM)and their mixtures 1:1:1(w/w)] were applied before cultivation in two recommended application rates low $\left(R_{1}\right)$ and high $\left(R_{2}\right)$. Three levels of soil moisture depletion regimes were used ( 30,50 and $70 \%$ ) from its available water capacity. The N,P,K mineral fertilizers were added according to the recommended doses for sandy soils. Applying natural soil conditioner types, their mixtures and application rates in the studied sandy soil subjected to moisture depletion regime realized improving soil chemical, physical, water holding capacity and macro nutritional status. Soil salinity (soil reaction, electrical conductivity and ionic strength), hazard sodium parameters (soluble sodium percentage and sodium adsorption ratio), soil porosity, available water capacity and phyto - available nutrients were increased. On the other hand, hydraulic conductivity and bulk density were decreased. Generally, high application rate achieved the best values of soil properties in comparison with low application rate. Conditioner mixtures 1:1:1 treatment realized the superiority under wheat pot experiment, meanwhile, compost treatment achieved the best values under maize field experiment. Irrigation after $50 \%$ AWSMD gave moderate values of such properties between wet (30\% AWSMD) and dry (70\% AWSMD). Increasing grains, straw, protein, grains weight, harvest index and other yield components significantly for wheat and maize crops, as a result of adding soil conditioners compared with control. Conditioner mixtures 1:1:1 treatment realized the superiority under wheat pot experiment, meanwhile, compost treatment achieved the best values under maize field experiment. Also, high application rate was better than low application rate. Results also indicated that, from view point of water and economic , the highest values of crop yield were obtained from irrigation at $50 \%$ depletion from its available water capacity rather than $30 \%$ and $70 \%$ respectively.

Keywords: Guelph permeameter apparatus; Time Domain Reflectometer (TDR apparatus); Composting; Nutrients - phytoavailability; Sandy soils; Water irrigation management; Soil conditioners; Cutthroat flumes. 


\section{INTRODUCTION}

Nowadays, the term of " sustainable agriculture " is widely used in world wide, which is keystone of the rational utilization of soils as one of our most important natural resources. It is the important aims of " sustainable agriculture » to protect and maintain of the multifunctions of soils (Varallyay, 2005). For preservation and sustainability the productivity of soil we have to take special regard to sandy soils having unfavorable properties. Sandy soil characterized by less than $18 \%$ clay and more than $68 \%$ sand in the first $100 \mathrm{~cm}$ of the soil depth are the poor soils that occur in many parts of the world (van Wambeke,1992). There are other problems facing agriculture sector caused by, mainly, inappropriate soil, water and fertile management practices as well as rapid decreasing of agricultural land particularly in Delta soils. Therefore, we have to find rapid solutions to face these problems. Sandy soils hold little water as the large pore spaces allow water to drain freely from soil. The productivity of these soils is limited by low water holding capacities, high infiltration rates, high evaporation, low inherent fertility levels, very low organic matter content and excessive deep percolation losses. Also, the water use efficiency of the crops cultivated in such soil is low.

Tackling these problems can be achieved through applying organic amendments, natural raw minerals and soil conditioners. These materials improve the retentative capacities of these soils and allow plants to get their water requirements and phyto -available nutrients easily.

Cereal crops such as (wheat and maize) are very strategically important crops in Egypt because it's constituent and indispensable part of Egyptian food diet. Generally, there is a great gap between the consumption and production of such crops. On the other hand, it is worthnoting that, the agriculture production in Egypt is mainly depend upon irrigated agriculture. The gap between supplies and demands of water is widening with increasing global population. We are suffering from this trouble, especially when we know that we are under water poverty limit. Because of the water limitation, one of the most important targets in the agriculture sector is how to save irrigation water and increase water use efficiencies. So, new techniques and practices are needed to achieve water save. Estimating irrigation water becomes important for project planning and irrigation management. The over irrigation practiced by the farmers usually leads to low irrigation efficiency. So it is necessary to ascertain to what extent the water in the root zone can be depleted to produce high economic yield with using little water applied . Planning best irrigation regimes is very important for maintaining available irrigation water. The proper water management ( irrigation scheduling ) not only accurates determination of crop water requirements but also helps to know when and how much water should be applied to get high efficiency of each unit of water. Regulated deficit irrigation is one of such practices. Many studies indicated that the deficit irrigation was a successful technique in crops irrigation, Omran(2005) and Seif et al.(2005). The main objectives of this investigation were to study and asses the effect of natural soil conditioner types, their mixtures and application rates in sandy soils subjected to irrigation regimes on: 
(i):Soil physico-chemical properties, moisture constants and nutritional status.

(ii):Agronomical production of wheat and maize crops after full maturity.

\section{MATERIALS AND METHODS}

Two selected sites represent arable sandy soil located at Abou-Omera Al-Sharkeya village , Baltim district, Kafr El-Sheikh Governorate $31^{\circ} 3440.6$ $\mathrm{N}$ latitude and $31^{\circ} 1055.5 \mathrm{E}$ longitude with an elevation of about 5 meters above sea level were chosen. Site 1 ( fruit field) was devoted for collecting composite surface soil sample for carrying out wheat pot experiment in plastic pots during the growing winter season period 2010/2011. Site 2 (nearby site 1) was occupied for conducting maize field experiment during growing summer season period 2011. After wheat and maize plants full maturity, representative composite disturbed soil surface samples were collected, air dried, crumbled by hand, homogenized and finely ground in steel mill to pass through 100 -mesh ( $0.15 \mathrm{~mm}$ opening sieve) and thoroughly mixed.

Generally, soil chemical characterizations of the studied soils before cultivation and directly after cereal crops harvesting as well as properties of the used matured co-compost and irrigation waters were performed using classical methods as reported and explained by Cottenie et al.(1982); Page et al.(1982); Carter(1993); Rowell (1996); Tan(1993) and Burt(2004) as tabulated in all Tables in this work. lonic strength $\left(\mathrm{mmoles}^{-1}\right)$ : was calculated using the following equation as explained by Tan(1993).

lonic strength (mmoles $\left.L^{-1}\right)=1 / 2 \sum_{i=1}^{i}{ }^{i} M_{i} z_{i}^{2}$

Where: $\mathrm{Mi}=$ conc. of ion (i) in mmoles $\mathrm{L}^{-1}$ and $\mathrm{Zi}=$ charge of ion ( $\mathrm{i}$ ).

Additionally, undisturbed vertical cylindrical volumes of field-moist soil samples were gently obtained using cylindrical sharp edged core samplers for estimating soil physical properties and soil moisture constants using routine work analysis methods as reported and described by Garcia(1978); Klute(1986); Okalebo et al.(1993) and Reynolds 1993(a,b). Soil moisture constants (field capacity, permanent wilting point and available water capacity) were measured and calculated by means of pressure cooker and pressure membrane apparatus for measuring moisture contents at pressures of 0.33 and 15 bar according to Garcia(1978) and reported by Klute(1986). Bulk and particle (real) densities were estimated as described by Blake and While, field saturated hydraulic conductivity in situ was determined using constant head well permeameter method employing Guelph permeameter apparatus as mentioned by Reynolds(1993b). All soil obtained values were calculated on oven dry weight basis $105 \mathrm{C}^{\circ}$ for 24 hours. Some chemical properties of the different irrigation water sources under consideration during the carrying out of pot and field experiment periods are listed in Table (3). The suitable experimental design was selected for both pot- and field experiments. The wheat pot experimental cross-sectional area was 0.0453 $\mathrm{m}^{2}$, while maize experimental plot area was $4.5 \mathrm{~m}^{2}(1.5 \times 3 \mathrm{~m})$. The experimental design was split-split plot arrangement with three replications. The main plots were devoted to three irrigation treatments as follows: Wet treatments (light irrigation) after $30 \%$ AWSMD from soil available water capacity; Medium - treatments (moderate irrigation) after $50 \%$ AWSMD from soil available water capacity ( $50 \%$ AWSMD)and Dry treatments (heavy 
irrigation)after $70 \%$ AWSMD from soil available water capacity $(70 \%$ AWSMD).Wheat and maize plants were exposed to deficit irrigation and started directly after life watering irrigation (El-Mohayaa irrigation) for achieving the selected available soil moisture depletion levels under consideration.Detailed experimental obtained data about irrigation scheduling and the actual seasonal applied water for wheat and maize crops production cultivated in loamy sand soils subjected to soil moisture depletion regimes over the growing winter and summer season periods 2010/2011 and 2011 are tabulated in Tables( 6 and 7$)$. The sub -plots were assigned to five types of soil conditioners and their mixtures $1: 1: 1(\mathrm{w} / \mathrm{w})$. The conditioner treatments (w/w) were applied as follows: Control (without additions); Bentonite at application rates of $0.2 \%$ and $0.3 \%$.; Co-compost at application rates of 0.3 $\%$ and $0.5 \%$; Mixture of Natural Raw Minerals (MNRM) at application rates of $0.2 \%$ and $0.3 \%$; and the mixtures of the three previous conditioners in 1:1:1 ratio at rates of $0.233 \%$ and $0.367 \%$. The soil conditioner treatments were randomly distributed in the three main plots.

Table (1): Initiative physico-chemical characteristics of the selected arable experimental sites under consideration located at Abou-Omera AlSharkeya village, Baltim district before planting

* Site(1): Properties of disturbed and undisturbed surface soil $(0-30 \mathrm{~cm})$ just before collection and transportation for wheat crop cultivation in pot-experiment.

* Site(2): Properties of disturbed and undisturbed surface soil just before cultivation of maize crop field -experiment. 
These conditioner types are mixed well with soil during its preparation for cultivating wheat before sowing and incorporated into soil surface before plowing during soil service process and its preparation before maize planting. Sub sub plots were occupied with two application rates as follows: $R_{1}$ and $R_{2}$ were (low) minimum and (high) maximum recommended application rates respectively Mixture Natural Raw Minerals (MNRM) and bentonite were purchased from Al-Ahram company for mining, natural minerals (ores) and fertilizers. These materials are the new products from Al-Ahram Company for improving soil properties and fertility. The chemical analysis of these materials listed in Table (4). The analytical data of elemental oxides were kindly obtained from Al-Ahram company. These natural minerals were used as soil conditioners for wheat pot - and maize-field experiments.

Seeds of wheat plants (Triticum aestivum, Sakha 93 variety) were obtained from Crop Agronomy Research Department, Sakha Agriculture Research Station, Ministry of Agriculture and Land Reclamation.Wheat potexperiment was conducted on experimental research area of Sakha Agriculture Research Station, Kafr El-Sheikh city. Pot experiment was performed using cylindrical perforated plastic pots having (mean internal diameter $24 \mathrm{~cm}$ and height $21 \mathrm{~cm}$ ) under wire proof greenhouse conditions. Pot cross-sectional area was $0.0453 \mathrm{~m}^{2}$ and its interval volume 9.504 liters. Composite loamy sand soil was collected and brought from fruit field (Site 1) located at Abou-Omera east village, Baltim district as mentioned before. Each pot contained $10 \mathrm{Kg}$ soil on oven dry weight basis, wheat cultivation elongated 135 days. Throughout the wheat growth period, a freely drained water was collected from each plastic pot and reused again with irrigation water and also whenever it was necessary.

Grains of maize plants (Zea mays, $L$ ) three cross 321 variety were obtained from Maize Research Center, Agriculture Research Center, Ministry of Agriculture and Land Reclamation. Maize field- experiment was carried out on cultivated area of Abou-Omera east village (Site 2), Baltim district during the growing summer season period 2011elongated 93 days. Total rented area $=3.5$ kyrat $=612.5 \mathrm{~m}^{2}$ and net cultivated area $405 \mathrm{~m}^{2}$ (90 plots). Experimental plot area was $4.5 \mathrm{~m}^{2}(1.5 \times 3)$ and its weight $1046.25 \mathrm{~kg}$ loamy sand soil on oven dry weight basis. 
Table (2): Soil moisture constants and its nutritional status of the selected experimental sites under consideration located at Abou-Omera AlSharkeya village, Baltim district before planting.

\begin{tabular}{|c|c|c|}
\hline \multirow[b]{2}{*}{ Soil variables } & \multicolumn{2}{|c|}{ Obtained values } \\
\hline & $\begin{array}{c}\text { Site }(1)^{\star} \\
\text { Pot-experiment }\end{array}$ & $\begin{array}{c}\text { Site }(2)^{\star \star} \\
\text { Field-experiment }\end{array}$ \\
\hline \multicolumn{3}{|c|}{ Soil moisture constants } \\
\hline Soil field capacity(S.F.C) & 17.0 & 18.0 \\
\hline Soil permanent wilting point(P.W.P) & 8.50 & 9.00 \\
\hline Soil available water capacity(A.W.C) & 8.50 & 9.00 \\
\hline \multicolumn{3}{|c|}{ Soil nutritional status } \\
\hline Total organic-C & 0.174 & 0.232 \\
\hline Organic matter(O.M) & 0.298 & 0.400 \\
\hline \multicolumn{3}{|c|}{ Available macro-nutrients } \\
\hline Available - N(K-sulphate extractable $) \mathrm{mgkg}^{-1}$ soil & 18.28 & 21.5 \\
\hline Available - $\mathrm{P}\left(\mathrm{NaHCO}_{3}\right.$ extractable $) \mathrm{mgkg}^{-1}$ soil & 7.62 & 8.90 \\
\hline $\begin{array}{l}\text { Available }-\mathrm{K}\left(\mathrm{NH}_{4} \text {-acetate extractable }\right) \quad \mathrm{mgkg}^{-1} \\
\text { soil }\end{array}$ & 50.15 & 53.5 \\
\hline \multicolumn{3}{|c|}{ Available micronutrients } \\
\hline Available - Fe(DTPA extractable) $\mathrm{mgkg}^{-1}$ soil & 6.00 & 6.50 \\
\hline Available - Mn(DTPA extractable) $\mathrm{mgkg}^{-1}$ soil & 4.45 & 5.00 \\
\hline Available-Zn(DTPA extractable) $\mathrm{mgkg}^{-1}$ soil & 1.20 & 1.10 \\
\hline Available - Cu (DTPA extractable) $\mathrm{mgkg}^{-1}$ soil & 0.34 & 0.66 \\
\hline
\end{tabular}

Notes : See feet notes of Table(1).

Aerobic / Thermophilic co-composting process was carried out at the experimental farm of Soil Improvement and Conservation Research Department, Sakha Agriculture Research Station during the summer growing season elongated five months from May 2010 to October 2010. Pyramidical piles(heaps) $2.5 \times 2.5 \times 1.5 \mathrm{~m}$ were built up under aerobic conditions. Different solid bio-wastes were used as substrates and augmented organically with farmyard manure $(10 \% \mathrm{w} / \mathrm{w})$ as microbial organic activator as well as with urea, super phosphate and potassium sulfate as microbial chemical activators. The other certain additional materials were incorporated into for speeding up the conversion and improving the final product quality and as growth promoting substances, $\mathrm{pH}$ buffering agents and as bulking agents. The obtained chemical and physical characteristics of the used matured co-compost after co- composting process are listed in Table (5). This matured co-compost was used as soil conditioner. 
J. Soil Sci. and Agric. Eng., Mansoura Univ., Vol. 5 (3), March, 2014

3 
Table (4): Chemical analysis of the used natural raw minerals and soil conditioners

\begin{tabular}{|c|c|c|}
\hline \multirow{2}{*}{ Characteristics } & \multicolumn{2}{|c|}{ Values } \\
\hline & Bentonite & MNRM \\
\hline \multicolumn{3}{|c|}{ Elemental oxides: \% } \\
\hline $\mathrm{SiO}_{2}$ & 55.9 & 39.36 \\
\hline $\mathrm{TiO}_{2}$ & 0.20 & 0.81 \\
\hline $\mathrm{Al}_{2} \mathrm{O}_{3}$ & 20.0 & 7.68 \\
\hline $\mathrm{Fe}_{2} \mathrm{O}_{3}$ & 0.70 & 4.05 \\
\hline $\mathrm{MnO}$ & 0.001 & 0.67 \\
\hline $\mathrm{MgO}$ & 0.65 & 3.20 \\
\hline $\mathrm{CaO}$ & 2.70 & 15.07 \\
\hline $\mathrm{Na}_{2} \mathrm{O}$ & 1.76 & 1.95 \\
\hline $\mathrm{K}_{2} \mathrm{O}$ & 2.40 & 3.94 \\
\hline $\mathrm{P}_{2} \mathrm{O}_{5}$ & 0.80 & 7.33 \\
\hline $\mathrm{SO}_{3}$ & - & 5.83 \\
\hline Loss on ignition & 10.0 & 9.14 \\
\hline ECe dS $m^{-1}(1: 10$ Bentonite-water extract(w/v) & 1.82 & \\
\hline $\mathrm{pH}(1: 2.5$ bentonite-water suspension (w/v) & 7.12 & \\
\hline \multicolumn{3}{|c|}{ Total soluble cations ( $\left.\mathrm{meq} \mathrm{L}^{-1}\right)(1: 5$ extracts $)$} \\
\hline 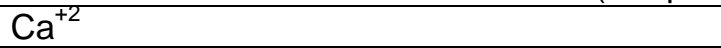 & 0.79 & \\
\hline $\mathrm{Mg}^{+2}$ & 0.27 & \\
\hline $\mathrm{Na}^{+}$ & 1.95 & \\
\hline $\mathrm{K}^{+}$ & 0.02 & \\
\hline \multicolumn{3}{|c|}{ Total soluble anions (meq $\left.\mathrm{L}^{-1}\right)(1: 5$ extracts $)$} \\
\hline $\mathrm{CO}_{3}{ }^{=}$ & - & \\
\hline $\mathrm{HCO}_{3}^{-}$ & 0.24 & \\
\hline $\mathrm{Cl}^{-}$ & 1.59 & \\
\hline $\mathrm{SO}_{4}{ }^{=}$ & 1.06 & \\
\hline Cation exchange capacity, cmoles $\mathrm{kg}^{-1}$ & 59.13 & \\
\hline Calcium carbonate \% & 14.27 & \\
\hline \multicolumn{3}{|c|}{ Particle size distribution $\%$} \\
\hline Clay fraction & 85.75 & \\
\hline Silt fraction & 10.54 & \\
\hline Sand fraction & 3.71 & \\
\hline
\end{tabular}

Notes:

1- MNRM: Mixture of Natural Raw Minerals

2- The analytical results of the elemental oxides were kindly obtained from Al-Ahram company for mining and natural fertilizers. 
Table (5): Chemical properties of the used co-compost directly after composting process

\begin{tabular}{|c|c|}
\hline Characteristics & Values \\
\hline Dry weight $\left(\mathrm{kg} \mathrm{m}^{-3}\right)$ & 650.0 \\
\hline Moisture content (\%) & 25.5 \\
\hline Odour and colour & Acceptable and dark \\
\hline $\mathrm{pH}(1: 10$ compost-water suspension w/v) & 7.16 \\
\hline EC (1:10 compost - water extraction w/v) & 5.23 \\
\hline Total soluble salts(soil paste -water extraction 1:10)\% & 0.335 \\
\hline Saturation percentage $\%$ ( $g / 100 \mathrm{~g}$ & 175.0 \\
\hline Total soluble salts (compost material)\% (g/100g compost) & 0.586 \\
\hline CEC (cmole kg-1) & 64.34 \\
\hline Total organic $-\mathrm{c} \%$ & 25.5 \\
\hline Total organic matter \% & 43.96 \\
\hline $\mathrm{C} / \mathrm{N}$ ratio & 21.98 \\
\hline \multicolumn{2}{|l|}{ Total macro-nutrients \% } \\
\hline Total - nitrogen & 1.16 \\
\hline Total - phosphorus \% & 0.53 \\
\hline Total - potassium \% & 0.37 \\
\hline \multicolumn{2}{|l|}{ Available macro-nutrients ( $\mathrm{mg} \mathrm{kg} \mathrm{compost)}$} \\
\hline Available - N (potassium sulfate) & 100 \\
\hline Available - P (0.5 M NaHCO $\left.3^{-}-\mathrm{pH} 8.5\right)$ & 50 \\
\hline Available - K (ammonium acetate $\mathrm{pH} 7)$ & 85 \\
\hline \multicolumn{2}{|l|}{ Available micro-nutrients ( $\mathrm{mg} \mathrm{kg} \mathrm{compost)}$} \\
\hline Available - Fe & 450 \\
\hline Available - Mn & 100 \\
\hline Available - Zn & 35 \\
\hline Available - Cu & 135 \\
\hline \multicolumn{2}{|l|}{ Total micro-nutrients ( $\mathrm{mg} \mathrm{kg} \mathrm{compost)}$} \\
\hline Total -Fe & 753 \\
\hline Total - Mn & 361 \\
\hline Total - Zn & 297 \\
\hline Total - Cu & 168 \\
\hline \multicolumn{2}{|c|}{ Available heavy metals ( $\mathrm{mg} \mathrm{kg} \mathrm{compost)}$} \\
\hline Available - cd & 13.2 \\
\hline Available - Ni & 62.7 \\
\hline Available - pb & 120 \\
\hline
\end{tabular}

\section{Irrigation water supply:}

Irrigation water supply and number of irrigations were limited according to the levels of soil moisture depletion regimes. Consequently, soil moisture content at demand depletion levels determines the timing of irrigation. Soil moisture content directly before irrigation at which calculated applied water must be added immediately for arriving at soil field capacity was measured in situ using TDR apparatus (Time Domain Reflectometert). Magnitude of irrigation applied water were calculated using the following soil moisture depletion equation as reported by (Israelson and Hansen, 1962) during wheat and maize growing season periods. 
El-Kammah,M.A.M. et al.

6 
J. Soil Sci. and Agric. Eng., Mansoura Univ., Vol. 5 (3), March, 2014

7 
Where: $\mathrm{Q}=$ Quantity of applied water $\mathrm{m}^{3}$ pot $^{-1}$ /irrigate for pot-experiment, and $\mathrm{m}^{3}$ plot $^{-1}$ /irrigate for field -experiment ;SFC = Soil field capacity (\%) in percent by volume; $\mathrm{CMC}=$ Soil moisture content just before irrigation using TDR apparatus; $B d=$ Soil bulk density $\mathrm{Mg} \mathrm{m}^{-3} ; \mathrm{D}=$ Soil depth $(\mathrm{m})$, effective root depth or soil depth required to be irrigated; and $A=$ pot or plot experimental area $\left(\mathrm{m}^{2}\right)$ that would be irrigated. With respect to maize field water measurements, the magnitude of planting and life watering irrigates were measured and applied using cutthroat flume $(20 \times 90 \mathrm{~cm})$ according to Early(1975).

A common NPK-fertilization was applied to the soil active root zone during the wheat and maize growing seasons according to the recommended doses of Ministry of Agriculture for wheat and maize crops under sandy soil conditions.

At harvesting time after wheat and maize plants full maturity, biomass grains and straw yields were fairly hand pulled and collected from each wheat pot experiment as well as from inner two rows of central area of maize plots. Some agronomical characteristics of these cereal crops and their productions such as (biomass grains, straw, biological yields and weight of 1000 wheat grains and 100 maize grains) as well as yield vegetative features as affected by soil conditioner types, their mixtures and application rates under irrigation deficits in the studied sandy soil were weight, measured, estimated, recorded and calculated some other parameters. Harvest index(\%) was calculated as follows:

$\mathrm{HI} \%=$ biomass grains yield $/$ biological crop yield $\times 100$

Statistical analysis:

Analysis of variance was done according to (Snedecor and Cochran, 1976) using the Irristat software, version 4.1 according to Biometrics Unit,1998, IRRI(1998).

\section{RESULTS AND DISCUSSION}

\section{Effect of applying soil conditioners under irrigation deficits on soil properties after cereal crops harvesting Chemical characteristics of soil suspensions and extractions:}

Concerning the effect of applying natural soil conditioner types, their mixtures(1:1:1) and application rates in sandy soils subjected to soil moisture depletion regimes (30\%, $50 \%$ and $70 \%)$ from their available water capacities

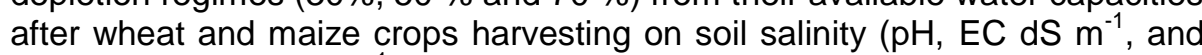
ionic strength mmole $\mathrm{L}^{-1}$ ) and hazard sodium parameters (SAR and SSP \%) are listed in Tables (8.1 and 8.2). Generally, the analytical chemicals results listed in aforementioned tables illustrate that values of these chemical parameters in the studied soil on the average of other studied parameters (irrigation treatments and conditioner application rates) were markedly increased due to the application of soil conditioner types in comparison with control values (without additions). These increase could be arranged in the following descending order as follow: Mixtures (1:1:1) > MNRM > Bentonite > Compost >> control . 
J. Soil Sci. and Agric. Eng., Mansoura Univ., Vol. 5 (3), March, 2014

8

351 
El-Kammah,M.A.M. et al.

8

352 
It is obviously that, the highest values were achieved as a result of mixtures application, meanwhile, the lowest values were obtained by dressing the compost treatment. However, the highest $\mathrm{pH}$ values were recorded at MNRM application under wheat pot experiment. Meanwhile, the lowest values of I.S were obtained at the application of bentonite under field-maize experiment.

On the other hand, these studied chemical properties, on the average of the other studied parameters (conditioner types, and their application rates), were markedly increased with increasing the depletion regimes from its soil available water capacity. Where, the highest values of these chemical parameters were achieved under dry treatment (70 \% AWSMD), meanwhile, the lowest values were recorded under wet treatment (30\% AWSMD). Medium treatment had the moderate values between wet and dry treatments. The analytical obtained increments could be rearranged in the following ascending order: Wet -treatment (30\% AWSMD) < Medium - treatment $(50$ $\%$ AWSMD) < Dry - treatment (70 \% AWSMD). This could be attributed to the dilution effect, since, salt concentration was decreased with increasing irrigation applied water. As delineated in Tables (8.1 and 8.2), obtained values of the studied chemical properties on the average of the other studied parameters (condition treatments and irrigation regime treatments)were higher under high application rate $\left(\mathrm{R}_{2}\right)$ rather than under low application rate $\left(R_{1}\right)$ at the same conditions. Data listed in Table (8.2) reveal also that under maize field experiment, the studied chemical properties were increased with adding soil conditioner types and their mixtures (1:1:1) on the overall average of the other studied parameters (irrigation treatments and conditioners application rates) in comparison with their control -values (without additions) at the same conditions. These parameters mannered the following descending order: Mixtures (1:1:1) > MNRM > Bentonite > Co-compost > Control. Generally, the obtained values of chemical properties after wheat crop harvesting were higher than those obtained after maize crop harvesting.

\section{Soil physical properties:}

Concerning the effect of natural soil conditioner types, their mixtures $1: 1: 1(\mathrm{w} / \mathrm{w})$ and application rates under soil moisture depletion levels from its available water capacity on soil physical properties after wheat and maize crops harvesting are presented in Tables(9.1 and 9.2). Generally, the results collected in Table(9.1) show that, on average of other studied parameters (irrigation treatments and conditioner application rates), that saturated hydraulic conductivity $\mathrm{SHC}\left(\mathrm{m}\right.$ day $\left.{ }^{-1}\right)$ and bulk density $\mathrm{D}_{\mathrm{b}}\left(\mathrm{Mg} \mathrm{m}^{-3}\right)$ were markedly decreased as a result of adding soil conditioner types and their mixtures (1:1:1) in the studied soil after wheat crop harvesting in comparison with their control values. The magnitude of these decrements which less the control values were depended upon the types of these conditioners. It is clearly that, the lowest values were achieved and accompanied with applying conditioner mixtures 1:1:1 (w/w) treatment. Meanwhile, the highest values were obtained with the dressing compost conditioner in comparison with their control values. These decrements could be arranged in the following descending order as follows: Mixtures 1:1:1 > MNRM > Bentonite > compost $>$ control. Oppositely, as demonstrated in the above mentioned Table, 
El-Kammah,M.A.M. et al.

9

354 
J. Soil Sci. and Agric. Eng., Mansoura Univ., Vol. 5 (3), March, 2014

9

355 
soil porosity values were mannered the opposite trend, where such values were increased over the control -values with adding soil conditioners and had the following sequence:

Mixtures $(1: 1: 1)<$ MNRM $<$ Bentonite $<$ Compost $<$ Control

Commonly, the obtained values of all studied physical properties on the average of the other studied parameters ( conditioner treatments and irrigation treatments) under the high application rate $\left(R_{2}\right)$ were lower than those obtained under the low application rate $\left(R_{1}\right)$. On the other hand, it was clearly apparent that, SHC values were gradually increased with increasing water irrigation deficits. However, $D_{b}$ and $\rho_{T}$ had the opposite trend, which decreased with increasing soil moisture depletion levels for its available water capacity. SHC - increments as well as $D_{b}$ and $\rho_{T}$ decrements with increasing moisture depletion levels could be arranged in the following descending order as follows:

Wet - treatment $(30 \%$ AWSMD) $>$ Medium - treatment $(50 \%$ AWSMD $)>$ Dry - treatment (70\% AWSMD)

In respect of maize field experiment, data demonstrated in Table (9.2) show on average of irrigation treatments that, application of all natural soil conditioner types and their mixtures (1:1:1) resulted in decreasing saturated hydraulic conductivity and soil bulk density, as well as led to increasing total porosity in comparison with their control values at the same conditions. It was clear that, conditioner mixtures $(1: 1: 1)$ realized the lowest values of SHC and $\rho_{T}$ besides the highest values of $D_{b}$ in comparison with their control values. However, application of co-compost treatment mannered the opposite trend, which gave the highest values of $\mathrm{SHC}$ and $\rho_{\mathrm{T}}$ in addition to the lowest values of $D_{b}$. Generally, it was apparent from the results that, on average of irrigation treatments and conditioner treatments that, adding high application rates lowered gradually SHC and $D_{b}$ and raised the values of $\rho_{\text {. }}$. In this direction, the low application rates led to the opposite trend. Commonly, analytical data listed in Tables (9.1 and 9.2) illustrate, on average of all other studied parameters(conditioner treatments and application rates) that, SHC and $\rho_{\mathrm{r}}$ values were gradually increased with increasing soil moisture depletion levels from its available water capacity. However, $D_{b}$ values were decreased with increasing irrigation deficits.

\section{Soil moisture constants:}

As concerns, field capacity (SFC \%), permanent wilting (PWP \%) and available water capacity (AWC\%) values of the studied sandy soils which reflect their soil water holding capacity after wheat and maize crops harvesting as affected by soil conditioner types, their mixtures and application rates under soil moisture depletion regimes, are presented in Tables (10.1 and 10.2) respectively. The obtained results, demonstrate, on average of the other studied parameters (irrigation treatments and conditioner -application rates) that, these soil moisture constants were obviously increased by applying soil conditioners and their mixtures (1:1:1) in comparison with their control values at the same conditions. 
J. Soil Sci. and Agric. Eng., Mansoura Univ., Vol. 5 (3), March, 2014

10 
El-Kammah,M.A.M. et al.

10

358 
Generally, these increments over the controls in studied soil after wheat crop harvesting could be arranged in the following sequence as follows:

Mixtures $(1: 1: 1)>$ MNRM $>$ Bentonite $>$ Compost $>$ Control

Regarding maize field experiment, data listed in Table (10.2) reveal, on average of other studied parameters that, values of soil moisture constants also were increased in comparison with their control values at the same conditions by applying soil conditioner types and their mixtures (1:1:1). These increments of all soil moisture constants in studied soil after maize crop harvesting could be rearranged in the following sequence as follows :

Compost $>$ Mixtures (1:1:1) > MNRM > Bentonite > Control

High conditioners application rate generally was realized higher values than those obtained by low conditioners application rate. As delineated in Table (10.1) it was clearly apparent on average of the other studied parameters, that these water properties were gradually decreased with increasing soil moisture depletion levels for its available water capacity. The highest values were achieved under wet - treatment (30\% AWSMD) while, the lowest values were given by dry - treatment (70\% AWSMD). Medium treatment $(50 \%$ AWSMD) recorded the moderate values of these soil moisture constants between wet(30 \% AWSMD) and $\operatorname{dry}(70 \%$ AWSMD)treatments.

Analytical results show that applying conditioner-mixtures (1:1:1) show its superiority over all other conditioner types under wheat -pot experiments. Meanwhile, applying compost treatment show its superiority over all other conditioner types under maize field experiment.

\section{Effect of applying soil conditioners under irrigation deficits on soil macronutrients content:}

Concerning residual contents (concentrations) of ( $\mathrm{N}$ and $\mathrm{P})$ after wheat and maize crops harvesting as affected by soil conditioner types, their mixtures and application rates subjected to irrigation deficits were listed in Table (11.1). Analytical results listed in this table reveal that, on average of other studied parameters (irrigation treatment and conditioner application rates), that $\mathrm{N}$ and $\mathrm{P}$ macronutrients content in studied sandy soils were increased by adding soil conditioner types and their mixtures (1:1:1) after wheat and maize crops harvesting in comparison with their control values.

The highest values of residual $\mathrm{N}$ and $\mathrm{P}$ were achieved and accompanied by mixtures (1:1:1) treatment. Meanwhile, dressing compost treatment gave lower values than those obtained by applying mixtures treatment in comparison with their control after pot wheat experiment at the same conditions.

Oppositely, residual $\mathrm{N}$ and $\mathrm{P}$ macro nutrients in the studied soil after maize crop harvesting behaved the opposite trend, where, the highest contents of these nutrients were achieved by applying compost treatment. However, the dressing conditioner mixtures gave values lesser than those obtained by adding compost treatment. The lowest values were absolutely obtained in the studied soil by adding bentonite treatment after either wheat or maize crop harvesting. These increments of the residual $\mathrm{N}$ and $\mathrm{P}$ 
macronutrients content after wheat crop harvesting could be arranged in the following sequence as follows:

Mixtures treatment $>$ MNRM $>$ Compost $>$ Bentonite $>$ Control. Moreover, on average of other studied parameters, obtained residual values of these macronutrients under high rate realized slightly values higher than those obtained under low application rate for either wheat or maize crops harvesting.

It was clearly apparent as delineated in Table (11.1) on average of other parameters, that content of macronutrients $(\mathrm{N}$ and $\mathrm{P})$ in the studied sandy soil after wheat and maize crops harvesting under medium -treatment $(50 \%$ AWSMD) were realized the highest values then under wet -treatment, while, the lowest values were obtained under dry-treatment. Residual contents of $\mathrm{N}$ and $\mathrm{P}$ macronutrients after maize crops harvesting could be also arranged in the following descending order: Compost treatment $>$ MNRM $>$ Mixtures > Bentonite > Control. Residual $\mathrm{N}$ and $\mathrm{P}$ macronutrients in studied sandy soils after wheat and maize crop harvesting could be arranged in the following descending order as: Medium -treatment (50\%AWSMD) > Wet treatment $(30 \%$ AWSMD) > Dry-treatment $(70 \%$ AWSMD). From the abovementioned results, it could be concluded that, on average other studied parameters, residual $\mathrm{N}$ and $\mathrm{P}$ macronutrients content in studied soils after crops harvesting means low exhausting nutrients from soils during the growing seasons of wheat and maize crops.

Effect of dressing soil conditioners under moisture depletion regimes on agronomical crops production

\section{Biomass grains and straw yields:}

Regarding wheat crop pot experiment after full maturity, data listed in Tables (12.1, 12.2 and 12.3) demonstrate, on average other studied parameters ( irrigation treatments and conditioner application rates), that application of soil conditioner types and their mixtures (1:1:1) resulted in significantly increasing wheat biomass grains yield, thousand grains weight, harvesting index and biomass straw yield in comparison with their control values at the same conditions.

Moreover, on average of the other studied parameters, the values of these agronomical features under high application rate $\left(R_{2}\right)$ were higher than those obtained under low application rate $\left(R_{1}\right)$. The increments of these agronomical traits could be arranged in the following descending order as: Mixtures (1:1:1) > MNRM > Bentonite > Compost > Control. So, the highest values of these agronomical features in studied sandy soils were achieved and accompanied by applying conditioner - mixtures treatment. Meanwhile, applying compost treatment gave the lowest values. However, the analytical obtained data, on average of the other studied parameters (conditioner treatments and their application rates) reveal that all agronomical features with the exception of harvest index were gradually decreased with increasing soil moisture depletion levels from its available water capacity. The magnitude of these decrements could be arranged in the following descending order as: Wet-treatment ( $30 \%$ AWSMD) $>$ Medium -treatment $(50 \%$ AWSMD $)>$ Dry -treatment $(70 \%$ AWSMD $)$. 
J. Soil Sci. and Agric. Eng., Mansoura Univ., Vol. 5 (3), March, 2014 
El-Kammah,M.A.M. et al.

12 
J. Soil Sci. and Agric. Eng., Mansoura Univ., Vol. 5 (3), March, 2014

12 
El-Kammah,M.A.M. et al.

12 
However, harvest index (\%) was slightly increased with increasing irrigation deficits. Therefore, these increments could be arranged in the following sequence as: Dry-treatment (70 \% AWSMD) > Medium-treatment $(50 \%$ AWSMD) $>$ Wet-treatment (30\% AWSMD).

Concerning field maize crop after full maturity, tabulated data show on average other parameters (irrigation treatments and conditioner application rates) that, dressing soil conditioner types and their mixtures 1:1:1 (w/w) led to increasing significantly biomass maize grains yield, hundred grains weight, harvesting index and biomass straw yield in comparison with their control values at the same conditions with the exception of harvest index. Moreover, the values of these agronomical features under high application rate $\left(R_{2}\right)$ gave higher values than those obtained under low application rate $\left(R_{1}\right)$ with exception of $\mathrm{H}$.I which behaved the opposite trend i.e. $\mathrm{R}_{1}>\mathrm{R}_{2}$. On the other hand, the obtained data under wet treatment (30\% AWSMD) on average of the other studied parameters (conditioners treatment) that compost treatment gave the highest values of these studied parameters except harvest index which had an opposite trend, where the highest values were obtained by adding their mixtures in comparison with compost application. It could be due to increasing straw yield of compost treatment as comparison with under their mixtures treatment. The lowest obtained values were generally recorded under bentonite treatment. However, such parameters under medium and dry treatments behaved the opposite trend in comparison with wet treatment, since the maximum values of biomass grains yield, 100 grain weight and harvest index were realized under mixtures treatment. Meanwhile, the biomass straw yield under compost treatment was higher than those obtained under mixture treatment. Generally, mean values of these parameters under medium treatment were higher than those obtained under wet and dry treatments and behaved the following order: Medium $>$ Wet $>$ Dry. Such results were obtained by Abdel-Reheem and Hassan (2011), they found that the highest values of wheat water productivity and yield were achieved when irrigation at $50 \%$ depletion from available water, compared to $70 \%$ and 40 $\%$ depletion in the loamy soils. confirming this conclusion, similar responses of maize crop production under field conditions was also reported by Khalifa (2013), who stated that, irrigation at $50 \%$ SMD gave the highest values of yield and its components of maize crop.

\section{Crop yield components:}

As regards to wheat and maize crops vegetative features after full maturity as affected by soil conditioner types, their mixtures and application rates subjected to different levels of irrigation deficits were presented in Tables (12.4 and 12.5). Obtained data shown in Table (12.4) reveal on average of the other studied parameters that, the following wheat crop vegetative features ( plant height, number of tillers/ spike; number of spikelets/spike; spike length and panicle mean weight were markedly increased as a result of adding soil conditioners and their mixtures 1:1:1 $(w / w)$. These increments could be arranged in the following descending order: 
El-Kammah,M.A.M. et al.

4

366 
J. Soil Sci. and Agric. Eng., Mansoura Univ., Vol. 5 (3), March, 2014

5 
Mixtures 1:1:1 treatment $>$ MNRM treatment $>$ Bentonite treatment $>$ Compost treatment $>$ Control. Furthermore, the mean values of these crop vegetative features under high application rate $\left(R_{2}\right)$ were higher than those obtained under low application rate $\left(R_{1}\right)$ i.e. $R_{2}>R_{1}$. On the other hand, on average of the other parameters, all these features were gradually decreased with increasing soil moisture depletion levels from its available water capacity. Consequently, these obtained decrements could be arranged in the following order as: Dry -treatment $(70 \%$ AWSMD) < Medium -treatment ( $50 \%$ AWSMD) < Wet-treatment (30\% AWSMD).

With respect to maize field crop vegetative features after full maturity, data were listed in Table (12.5). Obtained data show, on average of the other parameters, that some maize crop vegetative features such as plant height, ear weight, and ear length were obviously increased by adding soil conditioners and their mixtures 1:1:1 (w/w). High application rate $\left(R_{2}\right)$ recorded values higher than those obtained by low application rate $\left(R_{1}\right)$. So, under field experiment, compost treatment gave the high values in comparison with mixtures treatment at the same conditions, bentonite treatment realized the lowest values. Respecting irrigation regimes under field experiment, data show on average of the other studied parameters that medium -treatment ( $50 \%$ AWSMD) gave the highest values followed by wet -treatment (30\% AWSMD), while, dry -treatment recorded the lowest values.

\section{REFERENCES}

Abdel-Rheem , H.A. and A.F. Hassan(2011). Reducing of water use by water stress regime on some main field crops (wheat, soybean and corn). J. Soil. Sci . and Agric.Eng.,Mansoura Univ.,Vol.2(6):635-648.

Blake, G.R. and K.H. Hartge (1986 a). Bulk density. Pages 363 - 375. In A. Klute (ed.): Methods of Soil Analysis. Part 1 ( $2^{\text {nd }}$ Ed.): Physical and Mineralogical Methods. ASA, Inc., SSSA, Inc., Publisher Madison, Wisconsin, USA.

Blake, G.R and K.H. Hartage (1986 b). Particle density. Pages 377 - 382. In A. Klute (ed.): Methods of Soil Analysis. Part 1 ( ${ }^{\text {nd }}$ Ed.): Physical and Mineralogical Methods. ASA, Inc., SSSA, Inc., Publisher Madison, Wisconsin, USA.

Burt,R.(2004). "Soil Survey Laboratory Methods Manual". USDA - NRCS, Linoln, Nebraska.

Carter, M.R.(ed.).(1993). Soil Sampling and Methods of Analysis. Canadian Society of Soil Science. Lewis Publishers., Boca Raton, London, Tokyo.

Carter, M.R. and B.C.Ball(1993). Soil porosity. Pages 581 - 588. In M.R. Carter (ed.): Soil Sampling and Methods of Analysis. Canadian Society of Soil Science. Lewis Publishers, Boca Raton, London, Tokyo.

Cottenie, A.; P.M. Verloo; L.Kiekens ; G.Velghe and R. Camerlynck(1982). "Chemical Analysis of Plant and Soils". Lab.Anal. and Agrochem. State Univ., Gent, Belgium. 
Early,A.C.(1975). Irrigation scheduling for wheat in Punjab. Centosci Prog. Optimum use of water in agriculture, Rpt, 17, Layllpur, Pakistan, 3-5, March, Pages $115-127$.

El-Hady, O.A. and A.F. El-Sherif (1988). Egyptian bentonite deposits as soil conditioners. II: Hydro physical characteristics and mechanical strength of sandy soils treated with bentonite. Egypt. J. Soil Sci., 28: 215-223.

Garcia, I.(1978). Soil Water Engineering Laboratory Manual. Department of Agricultural and Chemical Engineering. Colorado State University, Fort Collins, Colorado, USA.

IRRI (1998). Using Irristat Software in Statistical Analysis. Manual, Biometrics Unit. Filipinas.

Israelson, O.W. and V.E.Hansen ( 1962 ). Irrigation Principles and Practices $\left(3^{\text {rd }}\right.$ Ed.). John Willey \& Sons Inc.,New York .

Khalifa, R.M.(2013). Water requirements of maize and sugar beet crops affected by soil moisture depletion and water table level. M.Sc. Thesis, Soil Sci. Dept. Fac. of Agric., Kafrelsheikh Univ.

Klute, A.(ed.)(1986). Methods of Soil Analysis, Part 1 (2 ${ }^{\text {nd }}$ Ed.): Physical and Mineralogical Methods. ASA,Inc., SSSA,Inc., Publisher, Madison, Wisconsin, USA.

Okalebo, J.R.; K. W. Gathua and P.L. Woomer (1993). Laboratory Methods of Soil and Plants Analysis: A Working Manual. TSBF Program, Soil Sci. Soc, of East Africa. Technical Publication. No.1, Unesco, Rosta, Kenya.

Omran,W.M.(2005). Maize yield response to available soil moisture. Minufiya J. Agric., Res., Egypt, 30(4): 1257 - 1268.

Page, A.L.; R.H. Miller and D.R. Keeney (eds.)(1982). Methods of Soil Analysis. Part 2 (2 ${ }^{\text {nd }}$ Ed.): Chemical and Microbiological Properties. ASA Inc., SSSA, Inc. Publisher, Madison, Wisconsin, USA.

Reynolds, W.D.(1993 a). Saturated hydraulic conductivity: Laboratory measurement. Pages 589 - 598. In M. R.Carter (ed.): Soil Sampling and Methods of Analysis. Canadian Society of Soil Science. Lewis Publishers, Boca Raton, London, Tokyo.

Reynolds, W.D.(1993 b). Saturated hydraulic conductivity: Field measurement. Pages, 599 - 613. In M. R.Carter (ed.): Soil Sampling and Methods of Analysis. Canadian Society of Soil Science. Lewis Publishers, Boca Raton, London, Tokyo.

Rowell,D.L.(1996). Soil Science: Methods and Applications. Longman,UK.

Seif, S.A., S.A.H. Allam; M.E.El-Emery and A.E.M. El- Galfy(2005). Effect of soil moisture depletion on growth, yield and yield components of some maize varieties. Annals of Agric.Sci., Moshtohor, 43(1): 25 - 58 .

Snedecer , G.W. and W.G.Cochran (1976). Statistical Methods $6^{\text {th }}$ (ed .), lowa State Univ . press, lowa, USA.

Tan,K.H.(1993). Principles of Soil Chemistry. (2 ${ }^{\text {nd }}$ Ed.). Page 62. Marcel Dekker Inc., New York.

van Wambeke,A.(1992). Soils of the Tropics - Properties and Appraisal. McGraw Hill,Inc., New York,USA. 
Várallyay G.Y. (2005): Role of soil multifunctionality in future sustainable agricultural development. Acta Agronomica Academiae Scientiarum Hungaricae, 51:109-124.

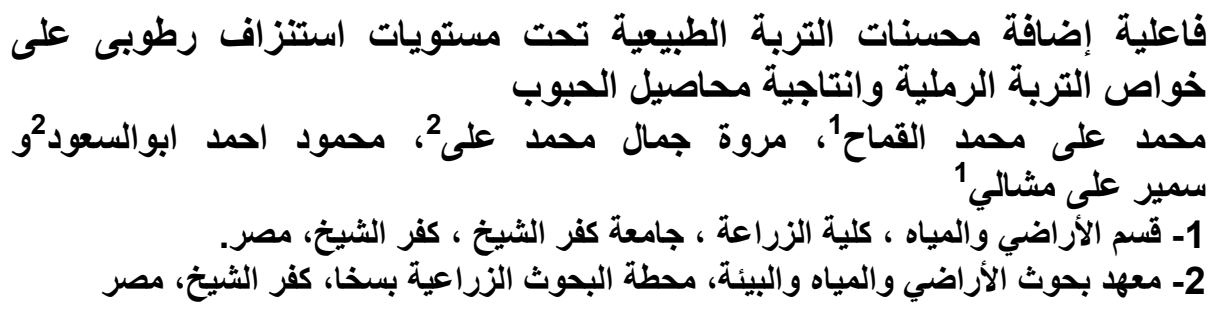

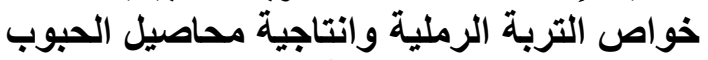

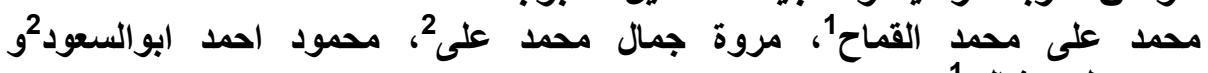

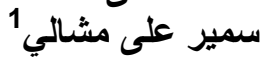

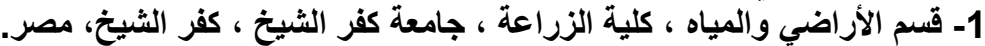

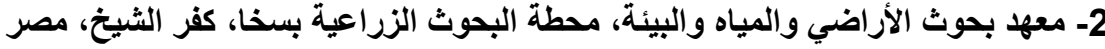

الهرف من البحث هو دراسة تأثير اضافة محسنات التربة الطبيعية ومخاليطها تحت مستويات من الاجهاد

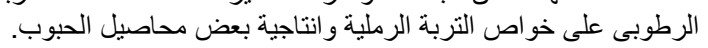
لهذا الغرض اقيمت تجربتان في موقعان يمثلان الأراضي الرئية الرملية بمصر بقرية ابوعميرة الثرقية، مركز

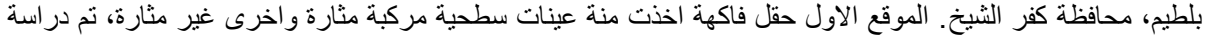

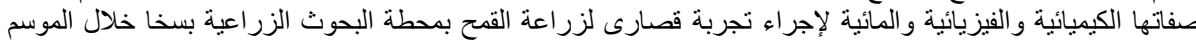

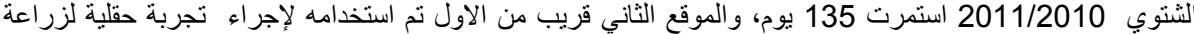

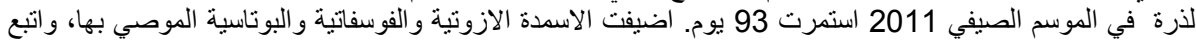
تصميم القطع منشقة المنشقة في ثلاث مكرر ات (90 وحدة تجريبية).

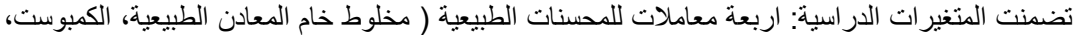

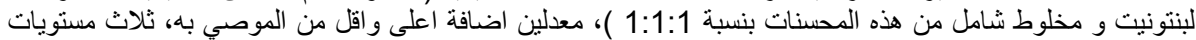

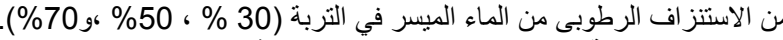

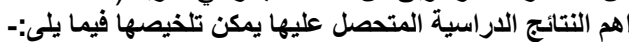

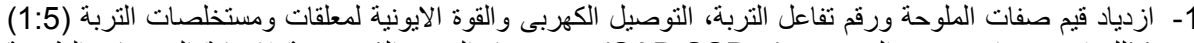

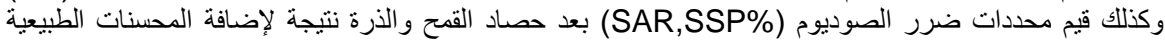

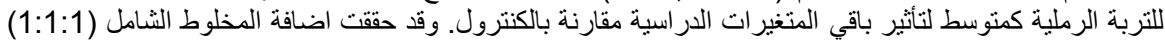

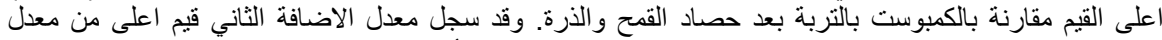

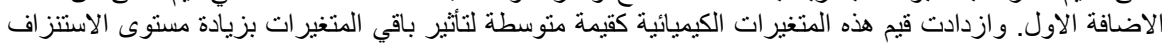

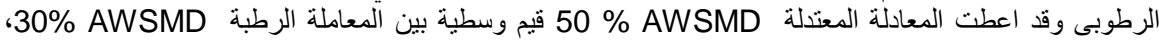

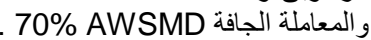

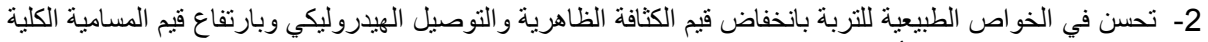

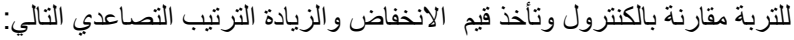
Mixtures (1:1:1) > MNRM > Compost > Bentonite > Control

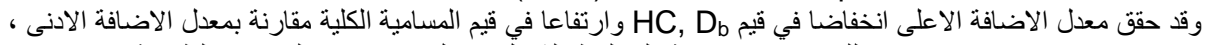

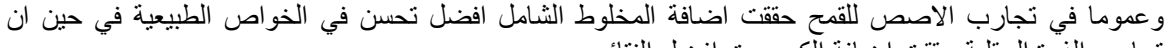

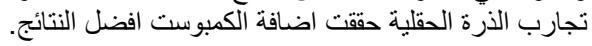
وقد ازدادت قيم الخواص الطبيعية بزيادة مستوى الاجهاد المائي فقد حققت المعاملة المعتدلة AWSMD \% 50 قبيم

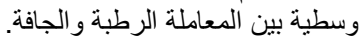

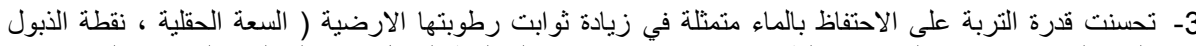

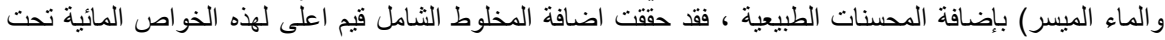

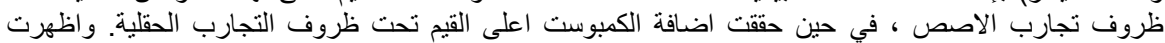

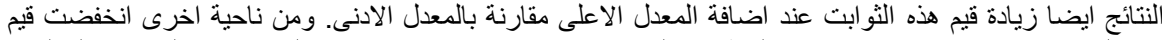

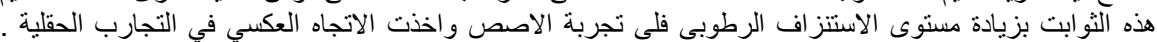

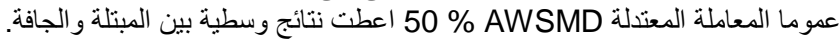

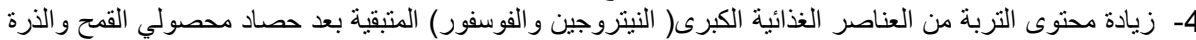

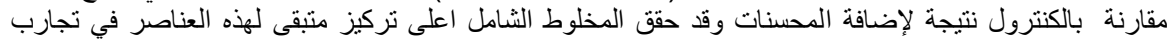

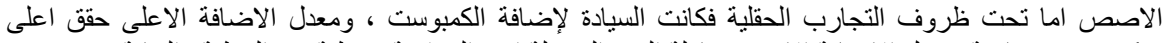

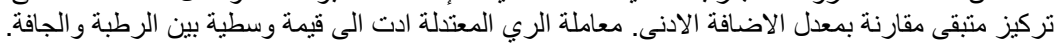

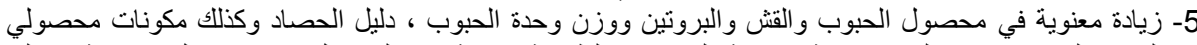
القمح و الذرة بعد تمام النضج نتيجة لإضافة المحسنات الطبيعية مقارنة بقيم الكنترول. وحقق لئن معدل الاضافة الاعلى 
J. Soil Sci. and Agric. Eng., Mansoura Univ., Vol. 5 (3), March, 2014

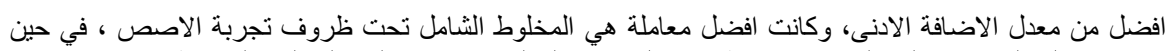

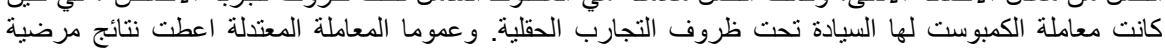
وسيطة بين المبتلة والجافة

كلية الزراعة ـ جامعة المنصورة أ. أد / أحمد عبد القادر طه

مركز البحوث الزراعيه أ.د / السيد عوض محمد المدار

قام بتحكيم البحث 

J. Soil Sci. and Agric. Eng., Mansoura Univ., Vol. 5 (3): 339-371, 2014

Table ( 6 ): Irrigation scheduling and actual seasonal applied water at different regular- intervals for wheat crop production cultivated in loamy sand soil under different soil moisture depletion regimes over the growing winter season period 2010/2011.

Notes : 1- Total applied water/season = calculated applied water +planting and life watering irrigations.

2-Life watering irrigation = El-Mohayaa irrigation 
Table ( 7 ): Irrigation scheduling and actual seasonal applied water at different regular - intervals for maize crop production cultivated in loamy sand soil under different soil moisture depletion regimes over the growing summer season period 2012.

\begin{tabular}{|c|c|c|c|c|c|c|c|c|c|}
\hline \multirow[t]{3}{*}{ Irrigation scheduling } & \multicolumn{3}{|c|}{$\begin{array}{c}\text { Wet - treatment } \\
30 \% \text { AWSMD } \\
\text { Light irrigation } \\
\text { Short- intervals(every day) }\end{array}$} & \multicolumn{3}{|c|}{$\begin{array}{c}\text { Medium- treatment } \\
50 \% \text { AWSMD } \\
\text { Moderate irrigation } \\
\text { Median -intervals(3 days) }\end{array}$} & \multicolumn{3}{|c|}{$\begin{array}{c}\text { Dry - treatment } \\
70 \% \text { AWSMD } \\
\text { Heavy irrigation } \\
\text { Long -intervals(8 days) } \\
\end{array}$} \\
\hline & \multirow{2}{*}{$\begin{array}{l}\text { Irrigation } \\
\text { date }\end{array}$} & \multicolumn{2}{|c|}{ Applied water } & \multirow{2}{*}{$\begin{array}{c}\text { Irrigation } \\
\text { date }\end{array}$} & \multicolumn{2}{|c|}{ Applied water } & \multirow{2}{*}{$\begin{array}{c}\text { Irrigation } \\
\text { date }\end{array}$} & \multicolumn{2}{|c|}{ Applied water } \\
\hline & & Lplot $^{-1}$ & $m^{3} \mathrm{fed}^{-1}$ & & Lplot $^{-1}$ & $m^{3} \mathrm{fed}^{-1}$ & & Lplot $^{-1}$ & $m^{3} \mathrm{fed}^{-1}$ \\
\hline $\begin{array}{l}\text { Planting irrigation } \\
\text { ( } 6.48 \% \text { SMC) }\end{array}$ & $5 / 7 / 2012$ & 241 & 224.6 & $5 / 7 / 2012$ & 241 & 224.6 & $5 / 7 / 2012$ & 241 & 224.6 \\
\hline $\begin{array}{l}\text { Life watering irrigation } \\
(9.75 \% \text { SMC) }\end{array}$ & 10/7/2012 & 172.6 & 161.12 & 10/7/2012 & 172.6 & 161.12 & 10/7/2012 & 172.6 & 161.12 \\
\hline \multicolumn{2}{|l|}{ Summation } & 413.6 & 385.7 & Summation & 413.6 & 385.7 & Summation & 413.6 & 385.7 \\
\hline Soil moisture content \% & \multicolumn{3}{|c|}{$15.33 \%$ SMC } & \multicolumn{3}{|c|}{$13.5 \%$ SMC } & \multicolumn{3}{|c|}{$11.7 \%$ SMC } \\
\hline Regular- intervals & \multicolumn{3}{|c|}{ Short- intervals ( every day) } & \multicolumn{3}{|c|}{ Median- intervals(3 days) } & \multicolumn{3}{|c|}{ Long- intervals (8 days) } \\
\hline First irrigate & $13 / 7 / 2012$ & 56.5 & 52.73 & 15/7/2012 & 94.17 & 87.89 & $18 / 7 / 2012$ & 244.82 & 228.5 \\
\hline Final irrigate & $27 / 9 / 2012$ & 56.5 & 52.73 & $25 / 9 / 2012$ & 94.17 & 87.89 & $20 / 9 / 2012$ & 244.82 & 228.5 \\
\hline Number of irrigates & \multicolumn{3}{|c|}{$\begin{array}{c}77 \text { irrigates plus planting and life } \\
\text { watering irrigations }\end{array}$} & \multicolumn{3}{|c|}{$\begin{array}{c}25 \text { irrigates plus planting and life } \\
\text { watering irrigations }\end{array}$} & \multicolumn{3}{|c|}{$\begin{array}{c}9 \text { irrigates plus planting and life } \\
\text { watering irrigations }\end{array}$} \\
\hline Total irrigation period & \multicolumn{3}{|c|}{$\begin{array}{c}86 \text { days } \\
5 / 7 / 2012-28 / 9 / 2012\end{array}$} & \multicolumn{3}{|c|}{$\begin{array}{c}86 \text { days } \\
5 / 7 / 2012-28 / 9 / 2012\end{array}$} & \multicolumn{3}{|c|}{$\begin{array}{c}86 \text { days } \\
5 / 7 / 2012-28 / 9 / 2012\end{array}$} \\
\hline Maize harvesting time & \multicolumn{3}{|c|}{ October $, 5,2012$} & \multirow{2}{*}{\multicolumn{3}{|c|}{$\begin{array}{l}\text { October , } 5,2012 \\
93 \text { days }\end{array}$}} & \multicolumn{3}{|c|}{ October , 5, 2012} \\
\hline Maize growing season period & & 93 days & & & & & & 93 days & \\
\hline \multirow{2}{*}{\multicolumn{2}{|c|}{$\begin{array}{l}\text { Calculated applied water /season } \\
\text { Total applied water/season }\end{array}$}} & 4351 & 4060 & & 2354 & 2197 & & 2203 & 2057 \\
\hline & & 4764 & 4446 & & 2768 & 2583 & & 2617 & 2442 \\
\hline
\end{tabular}


J. Soil Sci. and Agric. Eng., Mansoura Univ., Vol. 5 (3), March, 2014

Notes: Amounts of applied water for planting and life watering irrigations ( $\mathrm{ml} \mathrm{plot}^{-1} /$ irrigate) were measured using cutthroat flume $(20 \times 90)$ according to Early(1975). 
J. Soil Sci. and Agric. Eng., Mansoura Univ., Vol. 5 (3): 339-371, 2014 
Table (8.1): Soil salinity, sodicity and the ionic strength of its extracts after wheat crop harvesting as affected by natural soil conditioner types, their mixtures and application rates under different soil moisture depletion regimes.

\begin{tabular}{|c|c|c|c|c|c|c|c|c|c|c|c|c|c|c|c|c|c|}
\hline \multirow{5}{*}{$\begin{array}{l}\text { Soil } \\
\text { conditioner } \\
\text { types and } \\
\text { their } \\
\text { mixtures }\end{array}$} & \multirow{5}{*}{\multicolumn{2}{|c|}{$\begin{array}{l}\text { Conditioners } \\
\text { application } \\
\text { rates } \\
(w / w)\end{array}$}} & \multicolumn{15}{|c|}{ Soil moisture depletion levels from its available water capacity ( AWSM D-levels) } \\
\hline & & & \multirow{2}{*}{\multicolumn{5}{|c|}{$\begin{array}{c}\text { Wet- treatment } \\
(30 \% \text { AWSMD }) \\
\text { Light irrigation } \\
\text { Short - intervals }(3 \text { days }) \\
14.45 \% \text { SMC } \\
\end{array}$}} & \multirow{3}{*}{\multicolumn{5}{|c|}{\begin{tabular}{|c|}
$\begin{array}{c}\text { Medium - treatment } \\
\text { (50\% AWSMD) } \\
\text { Moderate irrigation } \\
\text { Median-intervals }(6 \text { days })\end{array}$ \\
$\mathbf{1 2 . 7 5} \%$ SMC \\
Chemical parameters
\end{tabular}}} & \multicolumn{5}{|c|}{$\begin{array}{c}\text { Dry-treatment } \\
\text { (70\% AWSMD) } \\
\text { Heavy irrigation } \\
\text { Long-intervals (9 days) }\end{array}$} \\
\hline & & & & & & & & & & & & & & & 11.08 & $\%$ SMC & \\
\hline & & & \multirow[b]{2}{*}{$\mathrm{pH}$} & & & & & & & & & & & & & & \\
\hline & & & & $\underset{\mathrm{dSm}}{E C}$ & \multicolumn{2}{|c|}{$\begin{array}{l}\text { H.S. } \\
\text { rrameters }\end{array}$} & ـ & $\mathrm{pH}$ & $\begin{array}{c}E C \\
\mathrm{dSm}^{-1}\end{array}$ & \multicolumn{2}{|c|}{$\begin{array}{c}\text { H.S. } \\
\text { parameters }\end{array}$} & ـ & $\mathrm{pH}$ & $\mathrm{dSm}^{-1}$ & \multicolumn{2}{|c|}{$\begin{array}{c}\text { H.S. } \\
\text { parameters }\end{array}$} & ــ" \\
\hline \multirow[b]{3}{*}{ Bentonite } & Withou & ditions & 7.80 & 0.32 & 2.86 & 64.71 & 3.64 & 7.60 & 0.35 & 2.86 & 63.36 & 4.45 & 7.40 & 0.44 & 3.26 & 63.13 & 5.36 \\
\hline & low & R1 & 8.06 & 88 & 3.76 & 62.50 & 8.63 & 8.12 & 0.62 & 3.85 & 62.69 & 8.78 & 8.30 & 0.75 & 4.1 & 62.82 & 9.88 \\
\hline & high & $\mathrm{R} 2$ & 8.20 & 0. & 4.20 & \begin{tabular}{|l|l|}
64.7 \\
\end{tabular} & 8.87 & 816 & 0.67 & 4.04 & & 9.64 & 8.14 & 0.87 & 4. & 63.41 & 10.12 \\
\hline \multicolumn{3}{|c|}{ Mean } & 8.13 & 0.63 & 3.98 & \begin{tabular}{|l|}
63.64 \\
\end{tabular} & 8.60 & 8.14 & 0.645 & 3.94 & 62. & 9.21 & 8.22 & 0.81 & 4.23 & & 10.00 \\
\hline \multirow[b]{2}{*}{ Compost } & low & R1 & 7.83 & 0.54 & 3.24 & \begin{tabular}{|l|}
60.00 \\
\end{tabular} & 6.76 & 8.12 & \begin{tabular}{|l|l|}
0.68 \\
\end{tabular} & 4.04 & 63. & 7.63 & 8.10 & 0.73 & 3.51 & 20 & 8.24 \\
\hline & high & $\mathrm{R} 2$ & 8.10 & 0.69 & 4.61 & 63.51 & 8.52 & 8.15 & 0.72 & 3.71 & 58.97 & 9.05 & 8.30 & 0.87 & 4.59 & 63.44 & 9.52 \\
\hline \multicolumn{3}{|c|}{ Mean } & 7.96 & & 3.92 & 61. & 7.64 & 8.13 & 0.70 & 3.87 & 60.99 & 8.34 & 8.20 & 0.80 & 4. & 62.32 & 8.88 \\
\hline \multirow[b]{2}{*}{ MNRM } & low & R1 & 8.13 & 0.81 & 4.11 & \begin{tabular}{|l|}
61.44 \\
\end{tabular} & 11.25 & 8.30 & 0.75 & 4.25 & 62 & 12.52 & 8.25 & 0.92 & 4.76 & 63.64 & 12.95 \\
\hline & high & $\mathrm{R} 2$ & 8.21 & 0.97 & 4.63 & 62.38 & 12.67 & \begin{tabular}{|l|}
8.18 \\
\end{tabular} & 0.74 & 4.24 & 63. & 13.28 & 8.40 & 0.94 & 4.77 & \begin{tabular}{|l|}
63.37 \\
\end{tabular} & 14.72 \\
\hline \multicolumn{3}{|c|}{ Mean } & \begin{tabular}{|l|}
8.17 \\
\end{tabular} & 0. & 4.37 & 61. & 11.96 & 8.24 & \begin{tabular}{|l|l|}
0.745 \\
\end{tabular} & 4.24 & 63 & 12.90 & 8.32 & 0.93 & 4.765 & 63.50 & 13.84 \\
\hline \multirow{2}{*}{$\begin{array}{c}\text { Their mixtures } \\
(1: 1: 1)\end{array}$} & low & R1 & 8.15 & 0.86 & 4.53 & 63. & 11.53 & 8.15 & \begin{tabular}{|l|}
1.20 \\
\end{tabular} & 5.47 & 64 & 13.65 & 8.20 & 1.01 & 5.00 & 63 & 14.66 \\
\hline & high & $\mathrm{R} 2$ & 8.15 & & 4.29 & 63. & 13.36 & 8.20 & 1.12 & 5.17 & 63 & 14.95 & 8.22 & 1.07 & & 48 & 15.28 \\
\hline \multicolumn{3}{|c|}{ Mean } & 8.15 & 0.995 & 4.41 & 63.33 & 12.45 & 8.17 & 1.16 & 5.32 & 63.69 & 14.30 & 8.21 & 1.04 & 5.05 & 63.68 & 14.97 \\
\hline \multirow{2}{*}{ Average } & low & R1 & \begin{tabular}{|l|}
8.04 \\
\end{tabular} & 0.698 & 3.90 & \begin{tabular}{|l|}
61.74 \\
\end{tabular} & 9.54 & \begin{tabular}{|l|l|}
8.17 \\
\end{tabular} & \begin{tabular}{|l|l|}
0.813 \\
\end{tabular} & 4.40 & 63.18 & 10.65 & 8.21 & 0.86 & 4.58 & 63.47 & 11.42 \\
\hline & high & $\mathrm{R} 2$ & 8.17 & 0.867 & 4.43 & 63.58 & 10.86 & 8.17 & 0.813 & 4.29 & 62.15 & 11.73 & 8.28 & 0.93 & 4.69 & 63.43 & 12.43 \\
\hline \multicolumn{3}{|c|}{ Overall mean } & $\begin{array}{l}8.10 \\
3\end{array}$ & 0.781 & 4.17 & 62.66 & 10.18 & 8.17 & 0.813 & 4.345 & 62.67 & 11.19 & 8.24 & 0.895 & 4.64 & 63.45 & 11.93 \\
\hline
\end{tabular}

3 replications and all obtained values were calculated on oven dry weight basis at $105 \mathrm{C}-$ for 24 hours.

2- Cylindrical plastic pots cross-sectional area $\left(0.0453 \mathrm{~m}^{2}\right)$ containing $10 \mathrm{~kg}$ loamy sand soil on oven dry weight irrigated with tap water 3-Winter growing season period of wheat crop elongated 135 days

4- Analytical data were determined and calculated using 1:5 soil water extracts (except $\mathrm{pH}$ )

5-Wet - treatment ( light irrigation ) : $30 \%$ AWSMD for short -intervals ( 3 days)and actual seasonal applied water was $1107.4 \mathrm{~m}^{3}$ fed $^{-1}\left(11.94 \mathrm{Lpot}^{-1}\right)$ 
8- SMC represents soil moisture content (\%) directly before irrigation at which calculated water applied must be applied immediately for arriving its field capacity.

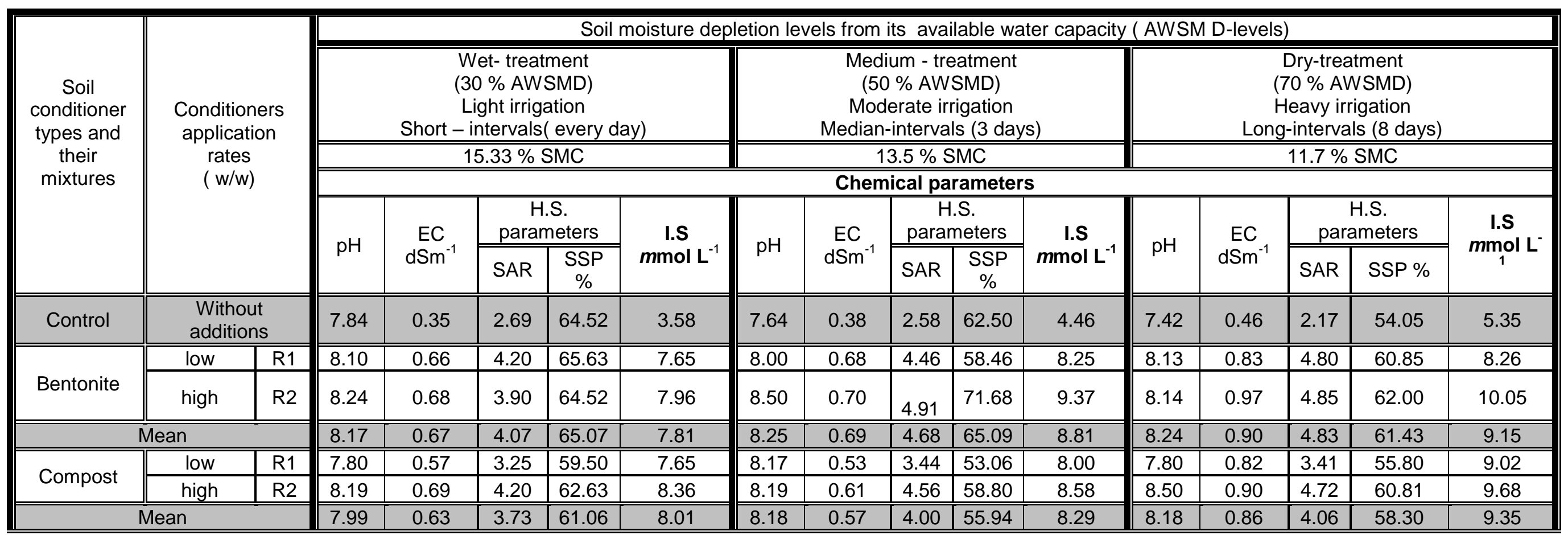


J. Soil Sci. and Agric. Eng., Mansoura Univ., Vol. 5 (3), March, 2014

\begin{tabular}{|c|c|c|c|c|c|c|c|c|c|c|c|c|c|c|c|c|c|}
\hline \multirow{2}{*}{ MNRM } & low & $\mathrm{R} 1$ & 8.10 & 0.85 & 4.15 & 61.05 & 10.13 & 8.23 & 0.74 & 3.38 & 57.97 & 10.08 & 8.05 & 0.92 & 4.09 & 59.78 & 10.62 \\
\hline & high & $\mathrm{R} 2$ & 8.16 & 0.97 & 4.32 & 62.50 & 12.45 & 8.28 & 0.75 & 4.66 & 67.56 & 11.36 & 8.50 & 0.94 & 4.66 & 64.44 & 11.40 \\
\hline \multicolumn{3}{|c|}{ Mean } & 8.13 & 0.91 & 4.24 & 61.78 & 11.29 & 8.25 & 0.745 & 4.02 & 62.77 & 10.72 & 8.30 & 0.93 & 4.38 & 62.11 & 11.01 \\
\hline \multirow{2}{*}{$\begin{array}{c}\text { Their } \\
\text { mixtures } \\
(1: 1: 1)\end{array}$} & low & $\mathrm{R} 1$ & 8.18 & 0.88 & 5.51 & 68.83 & 10.95 & 8.15 & 1.20 & 5.88 & 64.79 & 11.50 & 8.08 & 1.11 & 4.35 & 64.62 & 12.65 \\
\hline & high & $\mathrm{R} 2$ & 8.35 & 1.50 & 6.99 & 69.57 & 12.66 & 8.39 & 1.90 & 5.92 & 67.77 & 12.54 & 8.60 & 1.17 & 5.45 & 67.33 & 14.24 \\
\hline \multicolumn{3}{|c|}{ Mean } & 8.265 & 1.19 & 6.25 & 69.20 & 11.81 & 8.27 & 1.55 & 5.90 & 66.28 & 12.02 & 8.34 & 1.16 & 5.89 & 65.96 & 13.45 \\
\hline \multirow{2}{*}{ Average } & low & $\mathrm{R} 1$ & 8.05 & 0.74 & 4.28 & 63.75 & 9.10 & 8.14 & 0.79 & 4.29 & 58.57 & 9.46 & 8.07 & 0.90 & 4.16 & 60.26 & 10.39 \\
\hline & high & $\mathrm{R} 2$ & 8.23 & 0.96 & 4.85 & 64.79 & 10.36 & 8.33 & 0.99 & 5.01 & 66.47 & 10.45 & 8.45 & 0.96 & 5.42 & 63.14 & 11.34 \\
\hline \multicolumn{3}{|c|}{ Overall mean } & 8.139 & 0.85 & 4.56 & 64.27 & 9.73 & 8.237 & 0.89 & 4.65 & 62.57 & 9.96 & 8.265 & 0.963 & 4.79 & 61.70 & 10.86 \\
\hline
\end{tabular}

Table( 8.2): Soil salinity, sodicity and the ionic strength of its extracts after maize crop harvesting as affected by natural soil conditioner types, their mixtures and application rates under different soil moisture depletion regimes

Notes: $\quad$ 1- Each value is a mean of 3 replications and all obtained values were calculated on oven dry weight basis at $105 \mathrm{C}^{\circ}$ for 24 hours.

2- $\quad$ Analytical data were determined and calculated using 1:5 soil water extraction (except $\mathrm{pH}$ ).

3- $\quad$ Field plot sectional -area $4.5 \mathrm{~m}^{2}$ and its weight $1046.25 \mathrm{~kg}$ loamy sand soil on oven dry irrigated with drainage water (Kotshner).

4- $\quad$ Summer growing season period of maize crop elongated 93 days

5- Wet - treatment ( light irrigation ): $30 \%$ AWSMD for short -intervals ( every day)and actual seasonal applied water was $4446 \mathrm{~m}^{3}$ fed $^{-1}\left(4764\right.$ Lplot $\left.^{-1}\right)$

6- $\quad$ Medium - treatment (moderate irrigation): $50 \%$ AWSMD for median -intervals (3days)and actual seasonal applied water was $2583 \mathrm{~m}^{3}$ fed $^{-1}\left(2768 \mathrm{~L} \mathrm{plot}^{-1}\right)$

7- Dry - treatment ( heavy irrigation): $70 \%$ AWSMD for long -intervals ( 8 days)and actual seasonal applied water was $2442 \mathrm{~m}^{3} \mathrm{fed}^{-1}\left(2617 \mathrm{~L} \mathrm{plot}^{-1}\right)$ 
8- $\quad$ SMC represents soil moisture content ( \%) directly before irrigation at which calculated applied water must be done immediately to arrive its field capacity. 
J. Soil Sci. and Agric. Eng., Mansoura Univ., Vol. 5 (3): 339-371, 2014 
J. Soil Sci. and Agric. Eng., Mansoura Univ., Vol. 5 (3): 339-371, 2014

Table (9.1): Saturated hydraulic conductivity, bulk density and total porosity of studied soils after wheat crop harvesting as affected by natural soil conditioner types, their mixtures and application rates under different soil moisture depletion regimes .

\begin{tabular}{|c|c|c|c|c|c|c|c|c|c|c|c|}
\hline \multirow{5}{*}{$\begin{array}{c}\text { Soil conditioner } \\
\text { types and their } \\
\text { mixtures }\end{array}$} & \multirow{5}{*}{\multicolumn{2}{|c|}{$\begin{array}{l}\text { Conditioner } \\
\text { application } \\
\text { rates } \\
(\mathrm{w} / \mathrm{w})\end{array}$}} & \multicolumn{9}{|c|}{ Soil moisture depletion levels from its available water capacity( AWSMD-levels) } \\
\hline & & & \multicolumn{3}{|c|}{$\begin{array}{c}\text { Wet - treatment } \\
\text { (30\% AWSMD) } \\
\text { Light irrigation } \\
\text { Short - intervals } \\
\text { ( } 3 \text { days) }\end{array}$} & \multicolumn{3}{|c|}{$\begin{array}{c}\text { Medium - treatment } \\
\text { (50\% AWSMD) } \\
\text { Moderate irrigation } \\
\text { Median - intervals } \\
\text { (6 days) }\end{array}$} & \multicolumn{3}{|c|}{$\begin{array}{c}\text { Dry -treatment } \\
\text { (70\% AWSMD) } \\
\text { Heavy irrigation } \\
\text { Long-intervals } \\
\text { (9 days) } \\
\end{array}$} \\
\hline & & & \multicolumn{3}{|c|}{$14.45 \%$ SMC } & \multicolumn{3}{|c|}{$12.75 \%$ SMC } & \multicolumn{3}{|c|}{$11.08 \%$ SMC } \\
\hline & & & \multicolumn{9}{|c|}{ Physical parameters } \\
\hline & & & $\begin{array}{l}\text { SHC } \\
\text { m/day }\end{array}$ & $\begin{array}{c}\mathrm{D}_{\mathrm{b}} \\
\mathrm{Mg} / \mathrm{m}^{3}\end{array}$ & $\begin{array}{l}\rho_{\boldsymbol{T}} \\
\%\end{array}$ & $\begin{array}{l}\text { SHC } \\
\text { m/day }\end{array}$ & $\begin{array}{c}\mathrm{D}_{\mathrm{b}} \\
\mathrm{Mg} / \mathrm{m}^{3}\end{array}$ & $\begin{array}{l}\rho_{\boldsymbol{T}} \\
\%\end{array}$ & $\begin{array}{l}\text { SHC } \\
\text { m/day }\end{array}$ & $\begin{array}{c}D_{b} \\
M g / m^{3}\end{array}$ & $\begin{array}{l}\rho_{\boldsymbol{T}} \\
\%\end{array}$ \\
\hline Control & Witho & litions & 2.48 & 1.55 & 41.51 & 2.54 & 1.56 & 41.13 & 2.47 & 1.57 & 40.7 \\
\hline \multirow{2}{*}{ Bentonite } & low & R1 & 2.43 & 1.43 & 46.00 & 2.52 & 1.45 & 45.28 & 2.55 & 1.42 & 46.42 \\
\hline & high & $\mathrm{R} 2$ & 2.41 & 1.45 & 45.28 & 2.40 & 1.41 & 46.79 & 2.43 & 1.40 & 47.17 \\
\hline \multicolumn{3}{|c|}{ Mean } & 2.42 & 1.44 & 45.66 & 2.46 & 1.43 & 46.04 & 2.49 & 1.41 & 46.79 \\
\hline \multirow{2}{*}{ Compost } & low & $\mathrm{R} 1$ & 2.45 & 1.46 & 44.91 & 2.51 & 1.44 & 45.66 & 2.71 & 1.46 & 44.91 \\
\hline & high & $\mathrm{R} 2$ & 2.43 & 1.45 & 45.28 & 2.43 & 1.42 & 46.42 & 2.53 & 1.30 & 50.94 \\
\hline \multicolumn{3}{|c|}{ Mean } & 2.44 & 1.455 & 45.09 & 2.47 & 1.43 & 46.04 & 2.62 & 1.39 & 47.90 \\
\hline \multirow{2}{*}{ MNRM } & low & R1 & 2.40 & 1.44 & 45.66 & 2.40 & 1.44 & 45.66 & 2.41 & 1.45 & 45.28 \\
\hline & high & $\mathrm{R} 2$ & 2.38 & 1.43 & 46.00 & 2.36 & 1.40 & 47.17 & 2.37 & 1.35 & 49.06 \\
\hline \multicolumn{3}{|c|}{ Mean } & 2.39 & 1.435 & 45.85 & 2.38 & 1.42 & 46.42 & 2.39 & 1.40 & 47.17 \\
\hline
\end{tabular}


J. Soil Sci. and Agric. Eng., Mansoura Univ., Vol. 5 (3), March, 2014

\begin{tabular}{|c|c|c|c|c|c|c|c|c|c|c|c|}
\hline \multirow{2}{*}{$\begin{array}{c}\text { Their mixtures } \\
(1: 1: 1)\end{array}$} & low & $\mathrm{R} 1$ & 2.38 & 1.41 & 46.79 & 2.48 & 1.42 & 46.42 & 2.45 & 1.36 & 48.68 \\
\hline & high & $\mathrm{R} 2$ & 2.32 & 1.34 & 49.43 & 2.34 & 1.31 & 50.57 & 2.39 & 1.32 & 50.19 \\
\hline \multicolumn{3}{|c|}{ Mean } & 2.35 & 1.375 & 48.11 & 2.41 & 1.365 & 48.50 & 2.42 & 1.34 & 49.43 \\
\hline \multirow{2}{*}{ Average } & Iow & "R1 & 2.41 & 1.430 & 46.04 & 2.47 & 1.437 & 45.77 & 2.53 & 1.423 & 46.30 \\
\hline & high & $\mathrm{R} 2$ & 2.38 & 1.423 & 45.42 & 2.44 & 1.385 & 47.74 & 2.43 & 1.343 & 49.32 \\
\hline \multicolumn{3}{|c|}{ Overall mean } & 2.395 & 1.426 & 46.33 & 2.455 & 1.411 & 46.75 & 2.48 & 1.383 & 47.81 \\
\hline
\end{tabular}


Notes: 1-Each value is a mean of three replications and the obtained results were calculated on oven dry weight basis at $105 \mathrm{C}^{\circ}$ for 24 hours
2- SHC : Soil hydraulic conductivity
; $\mathbf{D}_{\mathbf{b}}$ : Soil bulk density and $\boldsymbol{\rho}_{\mathbf{t}}$ : Soil porosity in volume percent .

Table (9.2): Saturated hydraulic conductivity, bulk density and total porosity of studied soils after maize crop harvesting as affected by natural soil conditioner types, their mixtures and application rates under different soil moisture depletion regimes.

\begin{tabular}{|c|c|c|c|c|c|c|c|c|c|c|}
\hline \multirow{5}{*}{$\begin{array}{l}\text { Soil conditioner types } \\
\text { and their mixtures }\end{array}$} & \multirow{5}{*}{$\begin{array}{l}\text { Conditioner } \\
\text { application } \\
\text { rates } \\
(\mathrm{w} / \mathrm{w})\end{array}$} & \multicolumn{9}{|c|}{ Soil moisture depletion levels from its available water capacity( AWSMD-levels) } \\
\hline & & \multicolumn{3}{|c|}{$\begin{array}{c}\text { Wet - treatment } \\
\text { (30\% AWSMD) } \\
\text { Light irrigation } \\
\text { Short - intervals } \\
\text { ( every day) }\end{array}$} & \multicolumn{3}{|c|}{$\begin{array}{c}\text { Medium - treatment } \\
\text { (50 \% AWSMD) } \\
\text { Moderate irrigation } \\
\text { Median - intervals } \\
\text { (3days) }\end{array}$} & \multicolumn{3}{|c|}{$\begin{array}{c}\text { Dry -treatment } \\
\text { (70\% AWSMD) } \\
\text { Heavy irrigation } \\
\text { Long-intervals } \\
\text { (8 days) }\end{array}$} \\
\hline & & \multicolumn{3}{|c|}{$15.33 \%$ \%MC } & \multicolumn{3}{|c|}{$13.5 \%$ SMC } & \multicolumn{3}{|c|}{$11.7 \%$ SMC } \\
\hline & & \multicolumn{9}{|c|}{ Physical parameters } \\
\hline & & $\begin{array}{l}\text { SHC } \\
\text { m/day }\end{array}$ & $\begin{array}{c}D_{b} \\
M g / m^{3}\end{array}$ & $\begin{array}{l}\rho_{\text {T }} \\
\%\end{array}$ & $\begin{array}{l}\text { SHC } \\
\text { m/day }\end{array}$ & $\begin{array}{c}\mathrm{D}_{\mathrm{b}} \\
\mathrm{Mg} / \mathrm{m}^{3}\end{array}$ & $\begin{array}{l}\rho_{\mathrm{T}} \\
\%\end{array}$ & $\begin{array}{l}\text { SHC } \\
\text { m/day }\end{array}$ & $\begin{array}{c}D_{b} \\
M g / m^{3}\end{array}$ & $\begin{array}{l}\rho_{\mathrm{T}} \\
\%\end{array}$ \\
\hline Control & Without additions & 2.63 & 1.50 & 43.40 & 2.60 & 1.48 & 44.15 & 2.55 & 1.52 & 42.64 \\
\hline
\end{tabular}


J. Soil Sci. and Agric. Eng., Mansoura Univ., Vol. 5 (3), March, 2014

\begin{tabular}{|c|c|c|c|c|c|c|c|c|c|c|c|}
\hline \multirow{2}{*}{ Bentonite } & low & $\mathrm{R} 1$ & 2.60 & 1.41 & 46.79 & 2.84 & 1.35 & 49.06 & 2.55 & 1.42 & 46.41 \\
\hline & high & $\mathrm{R} 2$ & 2.32 & 1.33 & 49.80 & 2.31 & 1.30 & 50.94 & 2.40 & 1.22 & 53.96 \\
\hline \multicolumn{3}{|c|}{ Mean } & 2.46 & 1.364 & 48.34 & 2.575 & 1.33 & 49.81 & 2.475 & 1.32 & 50.19 \\
\hline \multirow{2}{*}{ Compost } & low & $\bar{R}$ R1 & 2.80 & 1.38 & 47.92 & 3.00 & 1.35 & 499.57 & 3.95 & 1.35 & 49.06 \\
\hline & high & $\mathrm{R} 2$ & 2.42 & 1.35 & 49.06 & 2.32 & 1.30 & 50.94 & 3.17 & 1.28 & 51.70 \\
\hline \multicolumn{3}{|c|}{ Mean } & 2.61 & 1.365 & 48.50 & 2.66 & 1.325 & 50.00 & 3.56 & 1.315 & 50.38 \\
\hline \multirow{2}{*}{ MNRM } & low & $\mathrm{R} \mathrm{R} 1$ & 2.64 & 1.40 & 47.17 & 2.50 & 1.28 & 51.70 & 2.86 & 1.38 & 47.92 \\
\hline & high & $\mathrm{R} 2$ & 2.20 & 1.34 & 49.43 & 2.48 & 1.40 & 47.17 & 3.10 & 1.30 & 50.94 \\
\hline \multicolumn{3}{|c|}{ Mean } & 2.42 & 1.37 & 48.30 & 2.49 & 1.34 & 49.44 & 2.98 & 1.34 & 49.43 \\
\hline \multirow{2}{*}{ Their mixtures $(1: 1: 1)$} & low & R1 & 2.44 & 1.39 & 477.54 & 2.38 & 1.38 & 47.92 & 2.30 & 1.37 & 48.30 \\
\hline & high & $\mathrm{R} 2$ & 2.34 & 1.37 & 48.30 & 2.35 & 1.35 & 49.06 & 2.00 & 1.32 & 50.19 \\
\hline \multicolumn{3}{|c|}{ Mean } & 2.39 & 1.38 & 47.92 & 2.365 & 1.365 & 48.40 & 2.15 & 1.35 & 49.06 \\
\hline \multirow{2}{*}{ Average } & low & $\mathrm{R} 1$ & 2.62 & 1.39 & 47.55 & 2.68 & 1.34 & 49.34 & 2.915 & 1.38 & 47.92 \\
\hline & high & $\mathrm{R} 2$ & 2.32 & 1.35 & 48.67 & 2.366 & 1.344 & 49.83 & 2.660 & 1.28 & 51.70 \\
\hline \multicolumn{3}{|c|}{ Overall mean } & 2.47 & 1.371 & 48.26 & 2.523 & 1.342 & 49.36 & 2.79 & 1.33 & 49.77 \\
\hline
\end{tabular}

Notes:1-Each value is a mean of three replications and the obtained results were calculated on oven dry weight basis at $105 \mathrm{C}^{\circ}$ for 24 hours.

2- SHC : Saturated hydraulic conductivity ; $D_{b}$ : Soil bulk density and $\rho_{t}$ : Total porosity( in volume percent). 
J. Soil Sci. and Agric. Eng., Mansoura Univ., Vol. 5 (3): 339-371, 2014 
J. Soil Sci. and Agric. Eng., Mansoura Univ., Vol. 5 (3): 339-371, 2014

Table(10.1): Field capacity, permanent wilting point and available water capacity of studied soils after wheat crop harvesting as affected by natural soil conditioner types, their mixtures and application rates under different soil moisture depletion regimes.

\begin{tabular}{|c|c|c|c|c|c|c|c|c|c|c|c|}
\hline \multirow{5}{*}{$\begin{array}{c}\text { Soil conditioner } \\
\text { types and their } \\
\text { mixtures }\end{array}$} & \multirow{5}{*}{\multicolumn{2}{|c|}{$\begin{array}{c}\text { Conditioner } \\
\text { application rates } \\
(\mathrm{w} / \mathrm{w})\end{array}$}} & \multicolumn{9}{|c|}{ "Soil moisture depletion levels from its available water capacity( AWSMD-levels) } \\
\hline & & & \multirow{2}{*}{\multicolumn{3}{|c|}{$\begin{array}{c}\text { Wet- treatment } \\
\text { (30\% AWSMD) } \\
\text { Light irrigation } \\
\text { Short - intervals } \\
\text { ( } 3 \text { days) } \\
14.45 \% \text { SMC } \\
\end{array}$}} & \multirow{2}{*}{\multicolumn{3}{|c|}{$\begin{array}{c}\text { Medium - treatment } \\
(50 \% \text { AWSMD) } \\
\text { Moderate irrigation } \\
\text { Median - intervals } \\
(6 \text { days }) \\
12.75 \% \text { SMC } \\
\end{array}$}} & \multirow{2}{*}{\multicolumn{3}{|c|}{$\begin{array}{c}\text { Dry - treatment } \\
\text { (70\% AWSMD) } \\
\text { Heavy irrigation } \\
\text { Long- intervals } \\
\text { (9 days) } \\
11.08 \% \text { SMC }\end{array}$}} \\
\hline & & & & & & & & & & & \\
\hline & & & \multicolumn{9}{|c|}{ "Soil moisture constants } \\
\hline & & & SFC\% & PWP \% & AWC \% & SFC\% & PWP \% & AWC\% & SFC\% & PWP \% & AWC\% \\
\hline Control & Withou & ditions & 17.0 & 8.5 & 8.5 & 16.6 & 8.2 & 8.4 & 16.4 & 8.2 & 8.2 \\
\hline \multirow{2}{*}{ Bentonite } & Low & $\mathrm{R} 1$ & 17.7 & 8.7 & 9.0 & 17.4 & 8.6 & 8.8 & 16.8 & 8.4 & 8.4 \\
\hline & High & $\mathrm{R} 2$ & 18.4 & 9.0 & 9.4 & 17.8 & 8.8 & 9.0 & 17.3 & 8.5 & 8.8 \\
\hline \multicolumn{3}{|c|}{ Mean } & 18.05 & 8.85 & 9.2 & 17.6 & 8.7 & 8.9 & 17.05 & 8.45 & 8.6 \\
\hline \multirow{2}{*}{ Compost } & Low & $\mathrm{R} 1$ & 17.7 & 8.8 & 8.9 & 17.3 & 8.5 & 8.8 & 17.2 & 8.5 & 8.7 \\
\hline & High & $\mathrm{R} 2$ & 18.1 & 8.8 & 9.3 & 18.5 & 8.9 & 9.6 & 17.5 & 8.8 & 8.7 \\
\hline \multicolumn{3}{|c|}{ Mean } & 17.9 & 8.8 & 9.1 & 17.9 & 8.7 & 9.2 & 17.35 & 8.65 & 8.7 \\
\hline \multirow{2}{*}{ MNRM } & Low & $\mathrm{R} 1$ & 19.2 & 9.5 & 9.7 & 18.5 & 9.2 & 9.3 & 17.9 & 8.9 & 9.0 \\
\hline & High & $\mathrm{R} 2$ & 19.5 & 9.8 & 9.7 & 18.7 & 9.3 & 9.4 & 18.2 & 9.0 & 9.2 \\
\hline
\end{tabular}


El-Kammah,M.A.M. et al.

\begin{tabular}{|c|c|c|c|c|c|c|c|c|c|c|c|}
\hline \multicolumn{3}{|c|}{ Mean } & 19.35 & 9.65 & 9.7 & 18.6 & 9.25 & 9.35 & 18.05 & 8.95 & 9.1 \\
\hline \multirow{2}{*}{$\begin{array}{c}\text { Their mixtures } \\
(1: 1: 1) \\
\end{array}$} & Low & R1 & 19.6 & 9.8 & 9.8 & 18.8 & 9.4 & 9.4 & 18.5 & 9.2 & 9.3 \\
\hline & High & $\mathrm{R} 2$ & 20.4 & 10.0 & 10.4 & 19.4 & 9.7 & 9.7 & 19.0 & 9.4 & 9.6 \\
\hline \multicolumn{3}{|c|}{ Mean } & 20.0 & 9.9 & 10.1 & 19.1 & 9.55 & 9.55 & 18.75 & 9.3 & 9.45 \\
\hline \multirow{2}{*}{ Average } & Low & $\mathrm{R} 1$ & 18.55 & 9.2 & 9.35 & 18.0 & 8.93 & 9.075 & 17.6 & 8.75 & 8.85 \\
\hline & High & $\mathrm{R} 2$ & 19.10 & 9.4 & 9.70 & 18.6 & 9.18 & 9.425 & 18.0 & 8.93 & 9.07 \\
\hline \multicolumn{3}{|c|}{ Overall mean } & 18.83 & 9.3 & 9.53 & 18.03 & 9.05 & 9.25 & 17.8 & 8.84 & 8.96 \\
\hline
\end{tabular}


Notes: 1-Each value is a mean of three replications and the obtained results were calculated on oven dry weight basis at $105 \mathrm{C}^{\circ}$ for 24 hours

2- SFC : soil field capacity ; PWP : permanent wilting point and AWC : soil available water capacity

Table(10.2): Field capacity, permanent wilting point and available water capacity of studied soils after maize crop harvesting as affected by natural soil conditioner types, their mixtures and application rates under different soil moisture depletion regimes.

\begin{tabular}{|c|c|c|c|c|}
\hline \multirow{3}{*}{$\begin{array}{c}\text { Soil } \\
\text { conditioner } \\
\text { types and } \\
\text { their } \\
\text { mixtures }\end{array}$} & \multirow{3}{*}{$\begin{array}{c}\text { Conditioner } \\
\text { application rates } \\
(\mathrm{w} / \mathrm{w})\end{array}$} & \multicolumn{3}{|c|}{ Soil moisture depletion levels from its available water capacity( AWSMD-levels) } \\
\hline & & $\begin{array}{c}\text { Wet- treatment } \\
\text { (30\% AWSMD) } \\
\text { Light irrigation } \\
\text { Short - intervals } \\
\text { ( every day) }\end{array}$ & $\begin{array}{l}\text { Medium - treatment } \\
\text { (50 \% AWSMD) } \\
\text { Moderate irrigation } \\
\text { Median - intervals } \\
\text { (3 days) }\end{array}$ & $\begin{array}{c}\text { Dry - treatment } \\
\text { (70 \% AWSMD) } \\
\text { Heavy irrigation } \\
\text { Long- intervals } \\
\text { (8 days) }\end{array}$ \\
\hline & & $15.33 \%$ \%MC & $13.5 \%$ SMC & $11.7 \%$ SMC \\
\hline
\end{tabular}


El-Kammah,M.A.M. et al.

\begin{tabular}{|c|c|c|c|c|c|c|c|c|c|c|c|}
\hline & & & \multicolumn{9}{|c|}{ Soil moisture constants } \\
\hline & & & SFC \% & PWP \% & AWC \% & SFC \% & PWP \% & AWC \% & SFC \% & PWP \% & AWC \% \\
\hline Control & \multicolumn{2}{|c|}{ Without additions } & 18.0 & 9.0 & 9.0 & 17.8 & 9.2 & 8.6 & 17.9 & 8.8 & 9.1 \\
\hline \multirow{2}{*}{ Bentonite } & Low & R1 & 18.5 & 9.3 & 9.2 & 18.3 & 9.5 & 8.8 & 19.2 & 9.0 & 10.2 \\
\hline & High & $\mathrm{R} 2$ & 18.9 & 9.5 & 9.4 & 18.8 & 9.6 & 9.2 & 19.8 & 9.2 & 10.6 \\
\hline \multicolumn{3}{|c|}{ Mean } & 18.7 & 9.4 & 9.3 & 18.55 & 9.55 & 9.0 & 19.5 & 9.1 & 10.4 \\
\hline \multirow{2}{*}{ Compost } & Low & R1 & 19.5 & 9.8 & 9.7 & 19.6 & 10.0 & 9.6 & 20.3 & 10.1 & 10.2 \\
\hline & High & $\mathrm{R} 2$ & 19.7 & 10.0 & 9.7 & 20.3 & 10.4 & 9.9 & 20.5 & 10.3 & 10.2 \\
\hline \multicolumn{3}{|c|}{ Mean } & 19.6 & 9.9 & 9.7 & 19.95 & 10.2 & 9.75 & 20.4 & 10.2 & 10.2 \\
\hline \multirow{2}{*}{ MNRM } & Low & R1 & 18.6 & 9.5 & 9.1 & $\overline{18.7}$ & 9.6 & 9.1 & 18.9 & 9.3 & 9.6 \\
\hline & High & $\mathrm{R} 2$ & 18.9 & 9.6 & 9.3 & 18.9 & 9.8 & 9.1 & 19.3 & 9.5 & 9.8 \\
\hline \multicolumn{3}{|c|}{ Mean } & 18.75 & 9.55 & 9.2 & 18.8 & 9.7 & 9.1 & 19.1 & 9.4 & 9.7 \\
\hline \multirow{2}{*}{$\begin{array}{c}\text { Their } \\
\text { mixtures } \\
(1: 1: 1) \\
\end{array}$} & Low & $\mathrm{R} 1$ & 19.4 & 9.7 & 9.7 & 19.5 & 9.9 & 9.6 & 19.8 & 9.8 & 10.0 \\
\hline & High & $\mathrm{R} 2$ & 19.5 & 9.8 & 9.7 & 19.7 & 10.0 & 9.7 & 20.2 & 10.2 & 10.0 \\
\hline \multicolumn{3}{|c|}{ Mean } & 19.45 & 9.75 & 9.7 & 19.6 & 9.95 & 9.65 & 20.0 & 10.0 & 10.0 \\
\hline \multirow{2}{*}{ Average } & Low & R1 & 19.0 & 9.58 & 9.43 & 19.02 & 9.75 & 9.275 & 19.55 & 9.55 & 10.0 \\
\hline & High & $\mathrm{R} 2$ & 19.25 & 9.73 & 9.53 & 19.43 & 9.95 & 9.476 & 19.95 & 9.8 & 10.15 \\
\hline \multicolumn{3}{|c|}{ Overall mean } & 19.12 & 9.65 & 9.47 & 19.23 & 9.85 & 9.375 & 19.75 & 9.67 & 10.07 \\
\hline
\end{tabular}


J. Soil Sci. and Agric. Eng., Mansoura Univ., Vol. 5 (3), March, 2014

Notes : 1-Each value is a mean of three replications and the obtained results ere calculated on oven dry weight basis at $105 C^{\circ}$ for 24 hours

2- SFC : soil field capacity ; PWP : permanent wilting point and AWC : soil available water capacity 
J. Soil Sci. and Agric. Eng., Mansoura Univ., Vol. 5 (3): 339-371, 2014 
J. Soil Sci. and Agric. Eng., Mansoura Univ., Vol. 5 (3): 339-371, 2014

Table(11.1): Phyto-availability (concentration) of soil macro-nutrients after wheat and maize crops harvesting as affected by natural soil conditioner types, their mixtures and application rates under different soil moisture depletion regimes.

\begin{tabular}{|c|c|c|c|c|c|c|c|c|c|c|c|c|c|c|}
\hline \multirow{5}{*}{$\begin{array}{c}\text { Soil } \\
\text { conditioner } \\
\text { types and } \\
\text { their } \\
\text { mixtures }\end{array}$} & \multirow{5}{*}{\multicolumn{2}{|c|}{$\begin{array}{l}\text { Conditioner } \\
\text { application } \\
\text { rates } \\
(\mathrm{w} / \mathrm{w})\end{array}$}} & \multicolumn{6}{|c|}{ After pot-wheat crop cultivation } & \multicolumn{6}{|c|}{ After field-maize crop cultivation } \\
\hline & & & \multirow{2}{*}{\multicolumn{2}{|c|}{$\begin{array}{c}\text { Wet- } \\
\text { treatment } \\
(30 \% \\
\text { AWSMD) } \\
\text { Light irrigation } \\
\text { Short - } \\
\text { intervals } \\
\text { ( } 3 \text { days) } \\
14.45 \% \text { SMC }\end{array}$}} & \multirow{2}{*}{\multicolumn{2}{|c|}{$\begin{array}{c}\text { Medium - } \\
\text { treatment } \\
(50 \% \\
\text { AWSMD) } \\
\text { Moderate } \\
\text { irrigation } \\
\text { Median - } \\
\text { intervals } \\
\text { (6 days) } \\
12.75 \% \text { SMC }\end{array}$}} & \multicolumn{2}{|c|}{$\begin{array}{c}\text { Dry - } \\
\text { treatment } \\
(70 \% \\
\text { AWSMD) } \\
\text { Heavy } \\
\text { irrigation } \\
\text { Long- intervals } \\
\text { (9 days) }\end{array}$} & \multicolumn{2}{|c|}{$\begin{array}{c}\text { Wet- } \\
\text { treatment } \\
(30 \% \\
\text { AWSMD) } \\
\text { Light irrigation } \\
\text { Short - } \\
\text { intervals } \\
\text { ( every day) }\end{array}$} & \multicolumn{2}{|c|}{$\begin{array}{c}\text { Medium - } \\
\text { treatment } \\
(50 \% \\
\text { AWSMD) } \\
\text { Moderate } \\
\text { irrigation } \\
\text { Median - } \\
\text { intervals } \\
\text { (3 days) }\end{array}$} & \multicolumn{2}{|c|}{$\begin{array}{c}\text { Dry - } \\
\text { treatment } \\
\text { (70\% } \\
\text { AWSMD) } \\
\text { Heavy } \\
\text { irrigation } \\
\text { Long- intervals } \\
\text { (8 days) }\end{array}$} \\
\hline & & & & & & & \multicolumn{2}{|c|}{$11.08 \%$ SMC } & \multicolumn{2}{|c|}{$15.33 \%$ \%MC } & \multicolumn{2}{|c|}{$13.5 \%$ SMC } & \multicolumn{2}{|c|}{$11.7 \%$ SMC } \\
\hline & & & \multicolumn{6}{|c|}{$\begin{array}{l}\text { Soil nutritional status } \\
\text { :ro-nutrients phytoavailability }\left(\mathrm{mg} \mathrm{kg}^{-1}\right. \\
\text { soil) }\end{array}$} & \multicolumn{6}{|c|}{$\begin{array}{l}\text { Soil nutritional status } \\
\text { nutrients phytoavailability ( } \mathrm{mg} \mathrm{kg}^{-1} \\
\text { soil) }\end{array}$} \\
\hline & & & $\mathbf{N}$ & $\mathbf{P}$ & $\mathbf{N}$ & $\mathbf{P}$ & $\mathbf{N}$ & $\mathbf{P}$ & $\mathbf{N}$ & $\mathbf{P}$ & $\mathbf{N}$ & $\mathbf{P}$ & $\mathbf{N}$ & $\mathbf{P}$ \\
\hline Control & \multicolumn{2}{|c|}{$\begin{array}{c}\text { Without } \\
\text { additions }\end{array}$} & 25.0 & 7.5 & 26.7 & 8.5 & 23.8 & 6.0 & 22.0 & 9.9 & 23.0 & 10.9 & 21.0 & 8.9 \\
\hline \multirow{2}{*}{ Bentonite } & low & R1 & 30.5 & 8.5 & 32.4 & 9.5 & 31.0 & 7.5 & 22.5 & 10.8 & 23.5 & 11.8 & 21.5 & 9.8 \\
\hline & high & $\mathrm{R} 2$ & 35.6 & 9.5 & 35.5 & 10.5 & 31.3 & 8.4 & 25.5 & 11.5 & 26.5 & 12.5 & 24.5 & 10.5 \\
\hline \multicolumn{3}{|c|}{ Mean } & 33.05 & 9.0 & 33.95 & 10.0 & 31.15 & 7.95 & 24.0 & 11.15 & 25.0 & 12.15 & 23.0 & 10.15 \\
\hline Compost & low & R1 & 38.5 & 8.7 & 34.8 & 9.7 & 35.0 & 7.8 & 35.5 & 13.1 & 36.5 & 14.1 & 34.5 & 12.1 \\
\hline
\end{tabular}


El-Kammah,M.A.M. et al.

\begin{tabular}{|c|c|c|c|c|c|c|c|c|c|c|c|c|c|c|}
\hline & high & R2 & 39.9 & 9.5 & 39.8 & 10.9 & 36.5 & 8.5 & 40.8 & 13.5 & 41.8 & 14.5 & 39.8 & 12.5 \\
\hline \multicolumn{3}{|c|}{ Mean } & 39.2 & 9.1 & 37.3 & 10.3 & 35.75 & 8.15 & 38.15 & 13.3 & 39.15 & 14.3 & 37.15 & 12.3 \\
\hline \multirow{2}{*}{ MNRM } & low & R1 & 37.8 & 10.2 & 46.5 & 11.2 & 37.2 & 9.2 & 30.2 & 12.5 & 31.2 & 11.5 & 29.2 & 11.5 \\
\hline & high & $\mathrm{R} 2$ & 40.5 & 10.5 & 47.3 & 11.5 & 40.0 & 9.9 & 35.3 & 12.8 & 36.3 & 13.8 & 34.3 & 11.8 \\
\hline \multicolumn{3}{|c|}{ Mean } & 39.15 & 10.35 & 46.9 & 11.35 & 38.6 & 9.55 & 32.75 & 12.65 & 33.75 & 12.65 & 31.75 & 11.65 \\
\hline \multirow{2}{*}{$\begin{array}{c}\text { Their } \\
\text { mixtures } \\
(1: 1: 1) \\
\end{array}$} & low & $\mathrm{R} 1$ & 43.5 & 11.2 & 49.3 & 12.2 & 43.0 & 10.2 & 36.3 & 12.9 & 37.3 & 13.9 & 35.3 & 11.9 \\
\hline & high & $\mathrm{R} 2$ & 46.5 & 13.9 & 49.5 & 14.9 & 44.5 & 12.9 & 39.5 & 13.2 & 40.5 & 14.2 & 38.5 & 12.2 \\
\hline \multicolumn{3}{|c|}{ Mean } & 45.0 & 12.55 & 49.4 & 13.55 & 43.75 & 11.55 & 37.9 & 13.05 & 38.9 & 14.05 & 36.9 & 12.05 \\
\hline \multirow{2}{*}{ Average } & low & R1 & 37.58 & 9.65 & 40.75 & 10.65 & 36.55 & 8.67 & 31.13 & 12.33 & 32.13 & 12.83 & 30.13 & 11.33 \\
\hline & high & $\mathrm{R} 2$ & 40.63 & 10.85 & 43.03 & 11.95 & 38.08 & 9.93 & 35.28 & 12.75 & 36.28 & 13.75 & 34.28 & 11.75 \\
\hline \multicolumn{3}{|c|}{ Overall mean } & 39.10 & 10.25 & 41.89 & 11.30 & 37.31 & 9.30 & 33.21 & 12.54 & 34.21 & 13.29 & 32.21 & 11.54 \\
\hline
\end{tabular}

Notes : 1 -Each value is a mean of 3 replications and all obtained values were calculated on oven dry weight basis at 105 Co for 24 hours

2-Each experimental plastic pot received ( w/w) $120.6 \mathrm{~kg}-\mathrm{N} \mathrm{fed}^{-1}\left(1.206 \mathrm{~g}-\mathrm{N} \mathrm{pot}^{-1}\right.$ ) as ammonium nitrate ( $33.5 \%$ $\mathrm{N}) ; 13.54 \mathrm{~kg}-\mathrm{P}$ fed $^{-1}\left(135.4 \mathrm{mg}^{-\mathrm{P}}\right.$ pot $\left.^{-1}\right)$ as normal super phosphate $\left(15.5 \% \mathrm{P}_{2} \mathrm{O}_{5}\right)$ and $28.8 \mathrm{~kg}^{-\mathrm{K}} \mathrm{fed}^{-1}\left(199.15 \mathrm{mg}^{-\mathrm{K}} \mathrm{pot}^{-1}\right)$ as potassium sulfate $\left(48 \% \mathrm{~K}_{2} \mathrm{O}\right)$.

3- Each experimental plot area received $260 \mathrm{~kg} \mathrm{fed}^{-1}$ urea $(46.5 \% \mathrm{~N})$ equivalent $0.127 \mathrm{~kg}-\mathrm{N} \mathrm{plot}^{-1} ; 200 \mathrm{~kg}^{-1} \mathrm{fed}^{-1}$ ordinary super phosphate $\left(15.5 \% \mathrm{P}_{2} \mathrm{O}_{5}\right)$ equivalent $\left(14.16 \mathrm{~g}-\mathrm{P} \mathrm{plot}^{-1}\right)$ and $50 \mathrm{~kg} \mathrm{fed}^{-1}$ potassium sulfate (48\% $\left.\mathrm{K}_{2} \mathrm{O}\right)$ equivalent

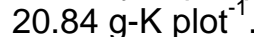


J. Soil Sci. and Agric. Eng., Mansoura Univ., Vol. 5 (3): 339-371, 2014 
J. Soil Sci. and Agric. Eng., Mansoura Univ., Vol. 5 (3): 339-371, 2014

Table(12.1): Biomass grains and straw yields of wheat and maize crops after full maturity as affected by natural soil conditioner types, their mixtures and application rates under wet-treatment (light irrigation) .

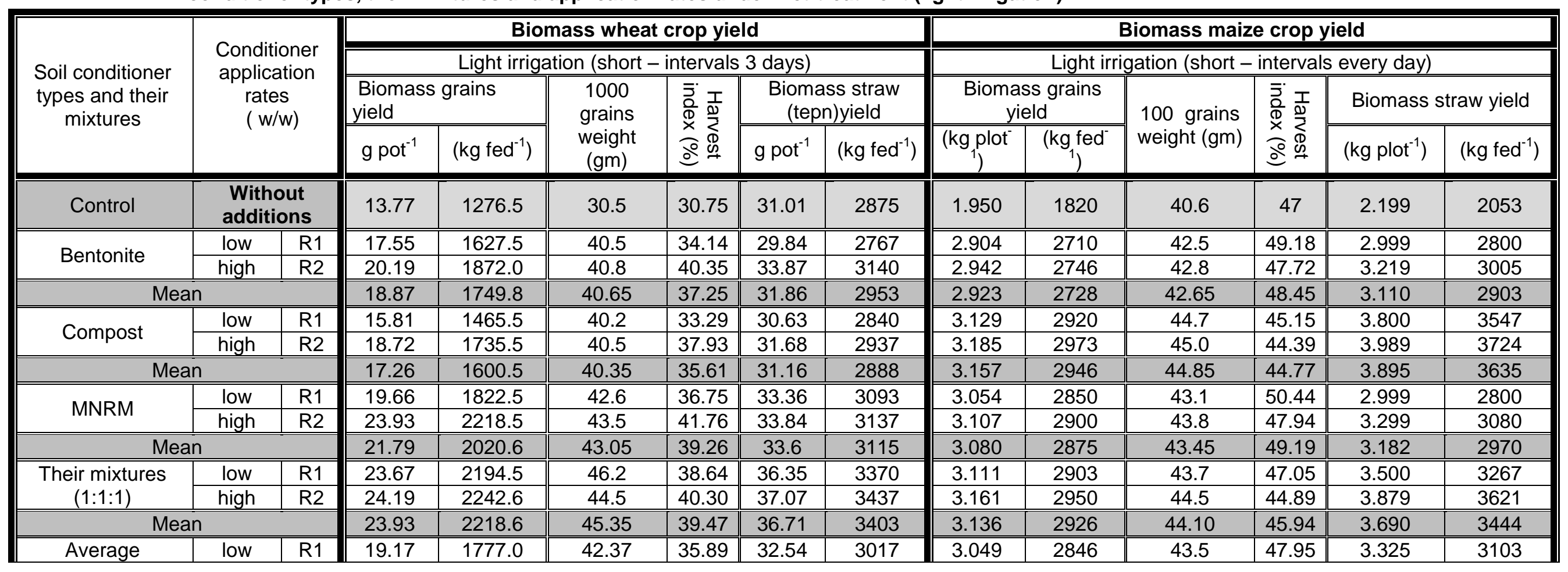


J. Soil Sci. and Agric. Eng., Mansoura Univ., Vol. 5 (3), March, 2014



Notes: 1- Each figure is a mean of 3 variables and all obtained data were calculated on oven dry weight basis at $70 \mathrm{C}-\mathrm{for} 18$ hours 2- Ardeb of wheat grains $=150 \mathrm{~kg}$ and heml straw $($ tepn $)=250 \mathrm{~kg}$, while, ardeb of maize grains $=140 \mathrm{~kg}$

3-Winter growing season elongated 135 days for wheat and growing summer season period elongated 93 days.

4- Wet - treatment (light irrigation): $30 \%$ AWSMD (short - intervals)( 3 days) for wheat and every day for maize crop.

Table(12.2): Biomass grains and straw yields of wheat and maize crops after full maturity as affected by natural soil conditioner types, their mixtures and application rates under medium-treatment (moderate irrigation).

\begin{tabular}{|c|c|c|c|c|c|c|c|c|c|c|c|c|c|c|}
\hline \multirow{4}{*}{$\begin{array}{c}\text { Soil } \\
\text { conditioner } \\
\text { types and } \\
\text { their } \\
\text { mixtures }\end{array}$} & \multirow{4}{*}{\multicolumn{2}{|c|}{$\begin{array}{c}\text { Conditioner } \\
\text { application rates } \\
(\mathrm{w} / \mathrm{w})\end{array}$}} & \multicolumn{6}{|c|}{ Biomass wheat crop yield } & \multicolumn{6}{|c|}{ Biomass maize crop yield } \\
\hline & & & \multicolumn{6}{|c|}{ Moderate irrigation (median - intervals 6 days) } & \multicolumn{6}{|c|}{ Moderate irrigation (median - intervals 3 days) } \\
\hline & & & \multicolumn{2}{|c|}{$\begin{array}{c}\text { Biomass grains } \\
\text { yield } \\
\end{array}$} & \multirow{2}{*}{$\begin{array}{c}1000 \\
\text { grains } \\
\text { weight } \\
\text { (gm) } \\
\end{array}$} & \multirow{2}{*}{ 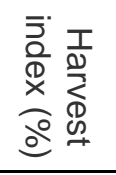 } & \multicolumn{2}{|c|}{$\begin{array}{c}\text { Biomass straw } \\
\text { (tepn)yield }\end{array}$} & \multicolumn{2}{|c|}{$\begin{array}{c}\text { Biomass grains } \\
\text { yield } \\
\end{array}$} & \multirow{2}{*}{$\begin{array}{c}100 \\
\text { grains } \\
\text { weight } \\
(\mathrm{gm}) \\
\end{array}$} & \multirow{2}{*}{ 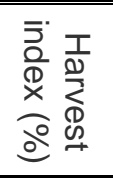 } & \multicolumn{2}{|c|}{ Biomass straw yield } \\
\hline & & & $\mathrm{g} \mathrm{pot}^{-1}$ & $\begin{array}{c}\mathrm{kg}_{1} \text { fed }^{-} \\
{ }^{\prime}\end{array}$ & & & $g \operatorname{pot}^{-1}$ & $\begin{array}{c}\mathrm{kg}_{1} \text { fed }^{-} \\
{ }^{\prime}\end{array}$ & $\begin{array}{c}\mathrm{kg}_{1} \mathrm{plot}^{-} \\
\end{array}$ & $\left(\mathrm{kg} \mathrm{fed}^{-1}\right)$ & & & $\left(\mathrm{kg} \mathrm{plot}^{-1}\right)$ & $\left(\mathrm{kg} \mathrm{fed}^{-1}\right)$ \\
\hline Control & $\begin{array}{r}\text { W } \\
\text { ad } \\
\end{array}$ & & 14.04 & 1302 & 30.6 & 32.69 & 28.91 & 2680 & 2.118 & 1977 & 41.2 & 42.46 & 2.870 & 2676 \\
\hline \multirow{2}{*}{ Bentonite } & low & $\mathrm{R} 1$ & 17.22 & 1596 & 40.3 & 36.25 & 30.28 & 2807 & 3.003 & 2803 & 42.6 & 499.21 & 3.099 & 2893 \\
\hline & high & $\mathrm{R} 2$ & 20.16 & 1869 & 40.6 & 37.89 & 33.04 & 3063 & 3.096 & 2890 & 43.5 & 49.17 & 3.200 & 2987 \\
\hline \multicolumn{3}{|c|}{ Mean } & 18.69 & 1732.5 & 40.4 & 37.07 & 31.66 & 2935 & 3.050 & 2846 & 43.05 & 49.19 & 3.150 & 2940 \\
\hline Compost & low & $\overline{\mathrm{R} \text { R } 1}$ & "15.97 & 1480.5 & 40.0 & 34.81 & 29.91 & 2773 & 3.204 & 2990 & 42.2 & 244.48 & 3.999 & 3733 \\
\hline
\end{tabular}


El-Kammah,M.A.M. et al.

\begin{tabular}{|c|c|c|c|c|c|c|c|c|c|c|c|c|c|c|}
\hline & high & $\mathrm{R} 2$ & 18.07 & 1675.5 & 40.2 & 36.84 & 30.98 & 2878 & 3.304 & 3084 & 45.2 & 44.03 & 4.199 & 3920 \\
\hline \multicolumn{3}{|c|}{ Mean } & 17.02 & 1578 & 440.1 & 35.82 & 30.45 & 2823 & 3.254 & 3037 & 43.7 & 444.26 & 4.100 & 3827 \\
\hline \multirow{2}{*}{ MNRM } & Iow & "R 1 & 19.25 & 1785 & 42.2 & 38.09 & 31.28 & 2900 & 3.107 & 2900 & 43.9 & 499.11 & 3.219 & 3005 \\
\hline & high & $\mathrm{R} 2$ & 22.81 & 2115 & 42.9 & 41.05 & 32.76 & 3037 & 3.204 & 2990 & 44.5 & 45.16 & 3.894 & 3631 \\
\hline \multicolumn{3}{|c|}{ Mean } & 21.03 & 1950 & 42.5 & 39.57 & 32.02 & 2969 & 3.155 & 2945 & 44.2 & 477.14 & 3.565 & 3318 \\
\hline \multirow{2}{*}{$\begin{array}{c}\text { Their } \\
\text { mixtures } \\
(1: 1: 1) \\
\end{array}$} & low & $\begin{array}{ll}\mathrm{R} 1 \\
\end{array}$ & 19.85 & 1840.5 & 43.6 & 38.56 & 31.63 & 2933 & 3.242 & 3026 & 44.5 & 444.83 & 3.989 & 3724 \\
\hline & high & $\mathrm{R} 2$ & 23.67 & 2194.5 & 45.2 & 40.85 & 34.27 & 3177 & 3.296 & 3076 & 45.0 & 44.89 & 4.100 & 3827 \\
\hline \multicolumn{3}{|c|}{ Mean } & 21.76 & 2017.5 & 44.4 & 39.77 & 32.95 & 3055 & 3.269 & 3051 & 44.75 & 44.86 & 4.045 & 3776 \\
\hline \multirow{2}{*}{ Average } & low & $\mathrm{R} 1$ & 18.07 & 1675.5 & 41.53 & 36.99 & 30.78 & 2853 & 3.139 & 2930 & 43.3 & 46.91 & 3.579 & 3338 \\
\hline & high & $\mathrm{R} 2$ & 21.178 & 1963.5 & 42.23 & 39.26 & 32.76 & 3038 & 3.225 & 3010 & 44.6 & 45.81 & 3.848 & 3591 \\
\hline \multicolumn{3}{|c|}{ Overall mean } & 19.63 & 1819.5 & 41.88 & 38.19 & 31.76 & 2946 & 3.182 & 2970 & 443.93 & 46.36 & 3.713 & 3465 \\
\hline
\end{tabular}

Notes: 1- Each figure is a mean of 3 variables and all obtained data were calculated on oven dry weight basis at 70 Cํ for 18 hours 2- Medium - treatment (moderate irrigation): $50 \%$ AWSMD (median - intervals)( 6 days) for wheat and 3 days for maize crop.

3- Harvest index $(\%)=\left[\right.$ Biomass grains yield $\left(\mathrm{g} \mathrm{pot}^{-1}\right) /$ Biological crop yield $\left.\left(\mathrm{g} \mathrm{pot}^{-1}\right)\right] \times 100$ on oven dry weight basis at $70 \mathrm{C}^{\circ}$ for 18 hours.

Table(12.3): Biomass grains and straw yields of wheat and maize crops after full maturity as affected by natural soil conditioner types, their mixtures and application rates under dry-treatment (heavy irrigation).

\begin{tabular}{||c|c||c||c|}
\hline Soil & & Biomass wheat crop yield & Biomass maize crop yield \\
\cline { 3 - 4 } $\begin{array}{c}\text { conditioner } \\
\text { types and }\end{array}$ & $\begin{array}{c}\text { Conditioner } \\
\text { application }\end{array}$ & Heavy irrigation (long - intervals 9 days) & Heavy irrigation (long - intervals 8 days) \\
\cline { 3 - 5 } & &
\end{tabular}


J. Soil Sci. and Agric. Eng., Mansoura Univ., Vol. 5 (3), March, 2014

\begin{tabular}{|c|c|c|c|c|c|c|c|c|c|c|c|c|c|c|}
\hline \multirow[t]{3}{*}{ their mixtures } & \multicolumn{2}{|c|}{ rates } & & & & & & & & & & & & \\
\hline & \multicolumn{2}{|c|}{$(w / w)$} & \multicolumn{2}{|c|}{$\begin{array}{c}\text { Biomass grains } \\
\text { yield }\end{array}$} & \multirow{2}{*}{$\begin{array}{c}1000 \\
\text { grains } \\
\text { weight } \\
(\mathrm{gm})\end{array}$} & \multirow{2}{*}{ 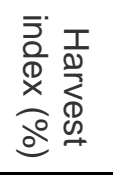 } & \multicolumn{2}{|c|}{$\begin{array}{l}\text { Biomass straw } \\
\text { (tepn)yield }\end{array}$} & \multicolumn{2}{|c|}{$\begin{array}{c}\text { Biomass grains } \\
\text { yield }\end{array}$} & \multirow{2}{*}{$\begin{array}{c}100 \\
\text { grains } \\
\text { weight } \\
(\mathrm{gm})\end{array}$} & \multirow{2}{*}{ 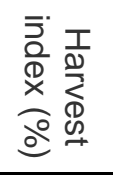 } & \multicolumn{2}{|c|}{$\begin{array}{c}\text { Biomass straw } \\
\text { yield }\end{array}$} \\
\hline & & & $\mathrm{g} \mathrm{pot}^{-1}$ & $\left(\mathrm{~kg} \mathrm{fed}^{-1}\right)$ & & & $\mathrm{g} \mathrm{pot}^{-1}$ & $\begin{array}{c}\mathrm{kg}_{1} \mathrm{fed}^{-} \\
\end{array}$ & $\begin{array}{c}\mathrm{kg}_{1} \text { plot }^{-} \\
\text {. }\end{array}$ & $\left(\mathrm{kg} \mathrm{fed}^{-1}\right)$ & & & $\left(\begin{array}{c}\mathrm{kg}_{1} \mathrm{plot}^{-} \\
-\end{array}\right.$ & $\left(\begin{array}{c}\mathrm{kg}_{1} \mathrm{fec} \\
)\end{array}\right.$ \\
\hline Control & \multicolumn{2}{|c|}{$\begin{array}{c}\text { Without } \\
\text { additions }\end{array}$} & 10.79 & 1000 & 30.3 & 34.45 & 20.53 & 1903 & 2.036 & 1900 & 40.0 & 49.22 & 2.099 & \\
\hline \multirow{2}{*}{ Bentonite } & low & R 1 & 13.09 & 1213 & 39.5 & 36.22 & 23.05 & 2137 & 2.818 & 2630 & 441.0 & 49.45 & 2.88 & 2688 \\
\hline & high & $\mathrm{R} 2$ & 18.38 & 1704 & 40.1 & 38.87 & 28.91 & 2630 & 2.807 & 2620 & 42.1 & 48.35 & 2.99 & 2800 \\
\hline \multicolumn{3}{|c|}{ Mean } & 15.74 & 1458 & 39.8 & 37.72 & 25.98 & 2408 & 2.812 & 2625 & 441.55 & 48.89 & 2.939 & 2744 \\
\hline \multirow{2}{*}{ Compost } & low & R 1 & 12.26 & 1137 & 38.9 & 33.24 & 24.62 & 2283 & 2.982 & 2783 & 41.2 & 46.43 & 3.44 & 3211 \\
\hline & high & $\mathrm{R} 2$ & 15.92 & 1476 & 40.1 & 37.41 & 26.64 & 2470 & 3.107 & 2900 & 42.3 & 44.4 & 3.89 & 3631 \\
\hline \multicolumn{3}{|c|}{ Mean } & 14.09 & 1306 & 39.5 & 35.47 & 25.63 & 2376 & 3.044 & 2841 & $4 \quad 41.74$ & 45.42 & 3.665 & 3421 \\
\hline \multirow{2}{*}{ MNRM } & low & R 1 & 15.06 & 1396 & 42.9 & 39.52 & 23.05 & 2137 & 2.989 & 2790 & 42.7 & 49.92 & 2.99 & 2800 \\
\hline & high & $\mathrm{R} 2$ & 24.79 & 2298 & 44.5 & 47.67 & 27.21 & 2523 & 3.001 & 2801 & 42.8 & 48.39 & 3.20 & 2987 \\
\hline \multicolumn{3}{|c|}{ Mean } & 19.93 & 1847 & 433.7 & 44.23 & 25.13 & 2330 & 2.995 & 2795 & 42.73 & 49.16 & 3.099 & 2893 \\
\hline \multirow{2}{*}{$\begin{array}{c}\text { Their } \\
\text { mixtures } \\
(1: 1: 1) \\
\end{array}$} & low & R 1 & 16.31 & 1512 & 42.5 & 35.79 & 29.26 & 2713 & 3.054 & 2850 & 42.5 & 477.83 & 3.33 & 3108 \\
\hline & high & $\mathrm{R} 2$ & 20.31 & 1882 & 44.2 & 40.06 & 30.38 & 2817 & 3.096 & 2890 & 44.0 & 46.59 & 3.54 & 3313 \\
\hline \multicolumn{3}{|c|}{ Mean } & 18.30 & 1697 & 43.4 & 38.02 & 29.82 & 2765 & 3.075 & 2870 & 43.25 & 47.21 & 3.44 & 3211 \\
\hline \multirow{2}{*}{ Average } & low & R 1 & 14.18 & 1314 & 40.95 & 36.2 & 24.99 & 2317 & 2.961 & 2763 & 41.9 & 48.41 & 3.16 & 2951 \\
\hline & high & $\mathrm{R} 2$ & 19.86 & 1840 & 42.51 & 41.23 & 28.29 & 2610 & 3.003 & 2803 & 42.7 & 46.93 & 3.41 & 3182 \\
\hline
\end{tabular}




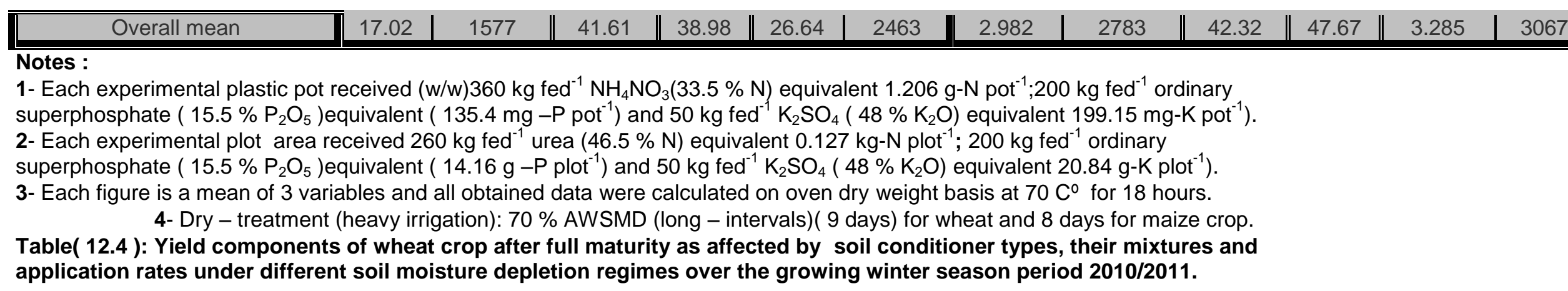

\begin{tabular}{|c|c|c|c|c|c|c|c|c|c|c|c|c|c|c|c|c|}
\hline \multirow{4}{*}{$\begin{array}{l}\text { Soil } \\
\text { conditioner } \\
\text { types and } \\
\text { their } \\
\text { mixtures }\end{array}$} & \multirow{4}{*}{$\begin{array}{l}\text { Conditioner } \\
\text { application } \\
\text { rates } \\
(\mathrm{w} / \mathrm{w})\end{array}$} & \multicolumn{15}{|c|}{ Soil moisture depletion levels from its available water capacity (AWSMD-levels) } \\
\hline & & \multirow{2}{*}{\multicolumn{5}{|c|}{$\begin{array}{c}\text { Wet - treatment } \\
\text { (30\% AWSMD) } \\
\text { Light irrigation } \\
\text { Short- intervals (3 days) } \\
14.45 \% \text { SMC }\end{array}$}} & \multicolumn{5}{|c|}{$\begin{array}{c}\text { Medium- treatment } \\
(50 \% \text { AWSMD) } \\
\text { Moderate irrigation } \\
\text { Median - intervals ( } 6 \text { days) }\end{array}$} & \multicolumn{5}{|c|}{$\begin{array}{c}\text { Dry -treatment } \\
\text { (70\% AWSMD) } \\
\text { Heavy irrigation } \\
\text { Long-intervals (9 days) }\end{array}$} \\
\hline & & & & & & & \multicolumn{5}{|c|}{ 12.75 SMC } & \multicolumn{5}{|c|}{$11.08 \%$ \%MC } \\
\hline & & 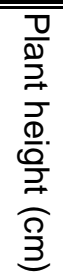 & 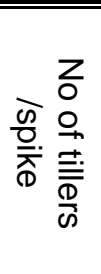 & 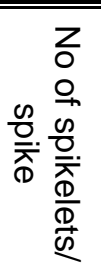 & 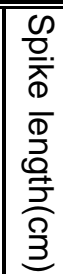 & 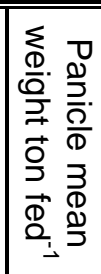 & $\begin{array}{l}\frac{0}{0} \\
\frac{0}{2} \\
\frac{1}{0} \\
\frac{\Phi}{0 .} \\
\frac{0}{7} \\
\frac{0}{3} \\
3\end{array}$ & 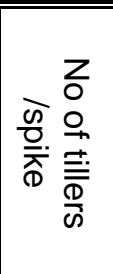 & 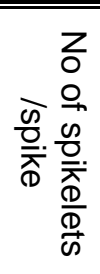 & 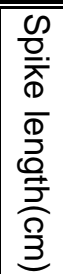 & 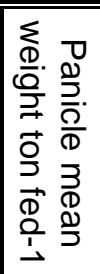 & 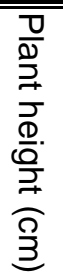 & 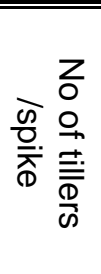 & 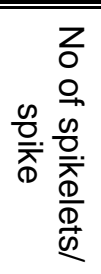 & 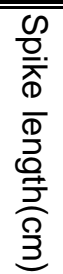 & 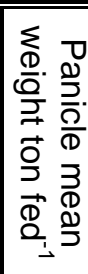 \\
\hline
\end{tabular}


J. Soil Sci. and Agric. Eng., Mansoura Univ., Vol. 5 (3), March, 2014

\begin{tabular}{|c|c|c|c|c|c|c|c|c|c|c|c|c|c|c|c|c|c|}
\hline Control & \multicolumn{2}{|c|}{$\begin{array}{l}\text { Without } \\
\text { additions }\end{array}$} & 79.5 & 2.2 & 17 & 10.8 & 1.0 & 77.5 & 3.3 & 17.2 & 10.7 & 1.32 & 72.5 & 3.2 & 16.8 & 10.5 & 1.19 \\
\hline \multirow{3}{*}{ Bentonite } & low & $\overline{\mathrm{R} 1}$ & 85.6 & 3.6 & 17.5 & 11.5 & 1.76 & 82.5 & 3.4 & 17.2 & 11.3 & 1.75 & 80.5 & 3.1 & 16.9 & 11.0 & 1.55 \\
\hline & high & $\mathrm{R} 2$ & 88.5 & 3.8 & 17.9 & 11.8 & 2.06 & 84.5 & 3.6 & 17.5 & 11.5 & 2.04 & 81.5 & 3.3 & 17.5 & 11.3 & 1.83 \\
\hline & \multicolumn{2}{|c|}{ Mean } & 87.05 & 3.7 & 17.7 & 11.65 & 1.91 & 83.5 & 3.5 & 17.35 & 11.4 & 1.895 & 81.0 & 3.2 & 17.2 & 11.15 & 1.69 \\
\hline \multirow[b]{2}{*}{ Compost } & low & $\mathrm{R} 1$ & 82.4 & 3.3 & 17.2 & 11.2 & 1.64 & 80.5 & 3.2 & 17.2 & 11.0 & 1.61 & 78.5 & 2.9 & 17.0 & 10.9 & 1.53 \\
\hline & high & $\mathrm{R} 2$ & 84.5 & 3.6 & 17.5 & 11.5 & 1.85 & 82.5 & 3.4 & 17.3 & 11.3 & 1.77 & 79.9 & 3.1 & 17.1 & 11.2 & 1.70 \\
\hline \multicolumn{3}{|c|}{ Mean } & 83.45 & 3.45 & 17.35 & 11.35 & 1.745 & 81.5 & 3.3 & 17.25 & 11.15 & 1.69 & 79.2 & 3.0 & 17.05 & 11.05 & 1.615 \\
\hline \multirow{3}{*}{ MNRM } & low & R1 & 88.5 & 4.2 & 18.5 & 11.8 & 1.65 & 87.5 & 3.9 & 18.2 & 11.5 & 1.71 & 83.5 & 3.2 & 18.0 & 10.9 & 1.67 \\
\hline & high & $\mathrm{R} 2$ & 90.5 & 4.5 & 18.8 & 12.3 & 1.90 & 89.5 & 4.2 & 18.5 & 12.1 & 1.87 & 85.5 & 3.8 & 18.2 & 11.8 & 1.80 \\
\hline & \multicolumn{2}{|c|}{ Mean } & 89.5 & 4.35 & 18.65 & 12.05 & 1.775 & 88.5 & 4.05 & 18.35 & 11.8 & 1.79 & 84.5 & 3.5 & 18.1 & 11.35 & 1.735 \\
\hline \multirow{2}{*}{$\begin{array}{l}\text { Their } \\
\text { mixtures } \\
(1: 1: 1)\end{array}$} & low & $\mathrm{R} 1$ & 91.5 & 4.6 & 19.2 & 12.0 & 2.03 & 90.5 & 4.3 & 18.8 & 11.9 & 2.00 & 85.5 & 4.0 & 18.4 & 11.5 & 1.88 \\
\hline & high & $\mathrm{R} 2$ & 92.5 & 4.7 & 19.8 & 12.8 & 2.37 & 91.5 & 4.6 & 19.5 & 12.5 & 2.37 & 87.4 & 4.3 & 19.2 & 12.2 & 2.12 \\
\hline \multicolumn{3}{|c|}{ Mean } & 92.0 & 4.65 & 19.5 & 12.4 & 2.20 & 91.0 & 4.45 & 19.15 & 12.2 & 2.185 & 86.45 & 4.15 & 18.8 & 11.85 & 2.00 \\
\hline \multirow[b]{2}{*}{ Average } & low & R1 & 91.3 & 4.5 & 19.2 & 12.3 & 2.09 & 90.3 & 4.35 & 18.95 & 12.1 & 2.08 & 85.96 & 3.98 & 18.6 & 111.7 & 1.93 \\
\hline & high & $\mathrm{R} 2$ & 91.8 & 4.6 & 19.44 & 12.3 & 2.17 & 90.84 & 4.42 & 19.10 & 12.1 & 2.16 & 86.32 & 4.10 & 18.7 & 11.81 & 1.98 \\
\hline \multicolumn{3}{|c|}{ Overall mean } & 91.6 & 4.6 & 19.36 & 12.34 & 2.10 & 90.6 & 4.38 & 19.02 & 12.13 & 2.12 & 86.14 & 4.04 & 18.69 & 11.77 & 1.95 \\
\hline
\end{tabular}

Notes: Each figure is a mean of 3 replicates.

Table( 5.5 ): Yield components of maize crop after full maturity as affected by soil conditioner types, their mixtures and application rates under different soil moisture depletion regimes over the summer growing season period 2011.

Soil conditioner types and

Soil moisture depletion levels from its available water capacity (AWSMD-levels) 
El-Kammah,M.A.M. et al.

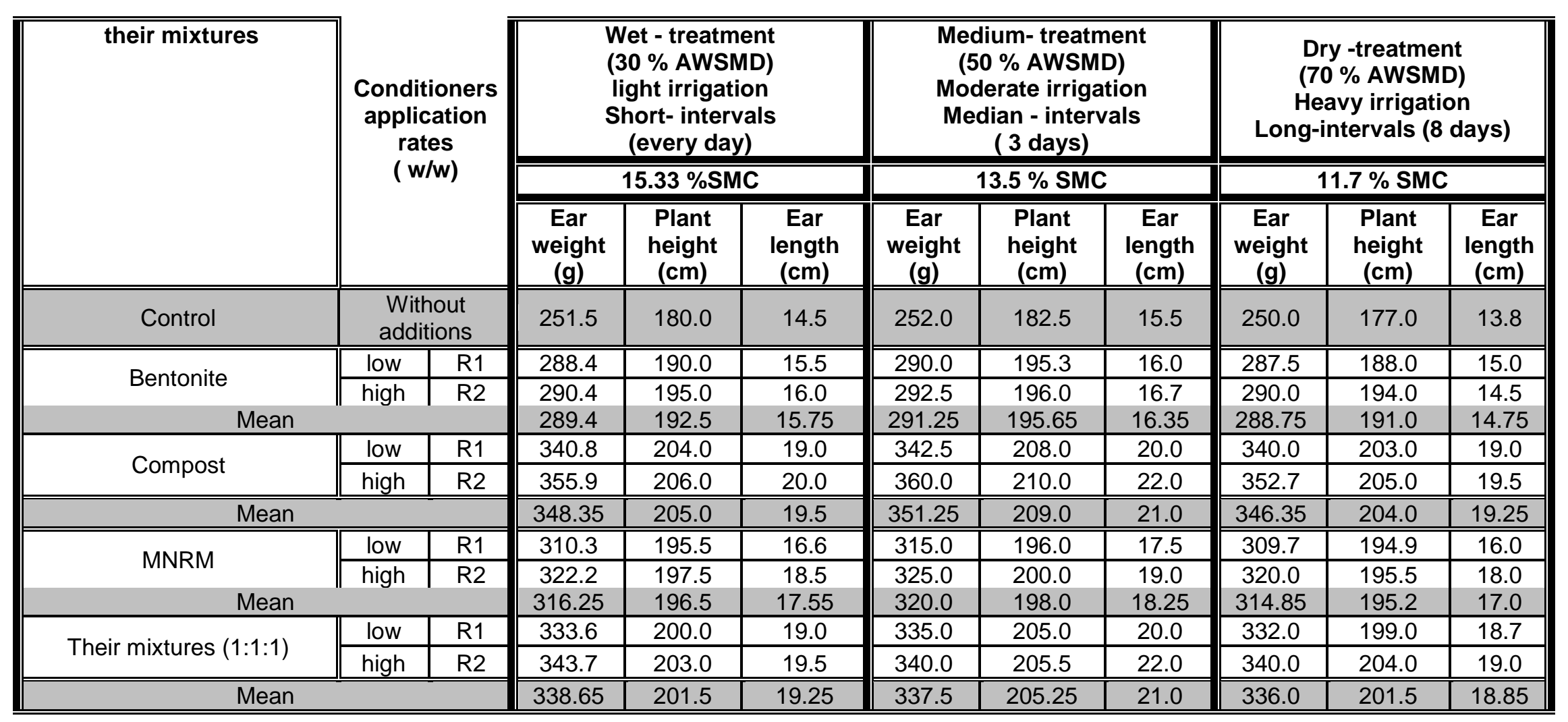


J. Soil Sci. and Agric. Eng., Mansoura Univ., Vol. 5 (3), March, 2014

\begin{tabular}{|c|c|c|c|c|c|c|c|c|c|c|c|}
\hline \multirow{2}{*}{ Average } & low & $\mathrm{R} 1$ & 318.27 & 197.37 & 17.52 & 320.6 & 201.07 & 18.37 & 317.3 & 196.22 & 17.05 \\
\hline & high & $\mathrm{R} 2$ & 328.05 & 200.37 & 18.50 & 329.4 & 202.87 & 19.92 & 325.7 & 199.63 & 17.38 \\
\hline \multicolumn{3}{|c|}{ Overall mean } & 323.16 & 198.87 & 18.01 & 324.98 & 201.97 & 19.14 & 321.48 & 197.92 & 17.21 \\
\hline
\end{tabular}

Notes: Each figure is a mean of 3 replicates. 
J. Soil Sci. and Agric. Eng., Mansoura Univ., Vol. 5 (3): 339-371, 2014 


\begin{tabular}{|c|c|c|}
\hline \multirow[b]{2}{*}{ Soil Characters } & \multicolumn{2}{|c|}{ Obtained values } \\
\hline & $\begin{array}{c}\text { Site }(1)^{\star} \\
\text { Pot-experiment }\end{array}$ & $\begin{array}{c}\text { Site }(2)^{\star \star} \\
\text { Field-experiment }\end{array}$ \\
\hline \multicolumn{3}{|l|}{ Chemical analysis } \\
\hline \multicolumn{3}{|c|}{  } \\
\hline Electrical conductivity, EC dS $m^{-1}$ (Soil past extract)at $25 \mathrm{C}^{0}$ & 2.60 & 3.75 \\
\hline Saturation percentage(S.P) & 38.0 & 40.0 \\
\hline Total soluble salts(T.S.S) & $632(0.063 \%)$ & $960(0.096 \%)$ \\
\hline Calcium carbonate $\left(\mathrm{CaCO}_{3}\right)$ & 0.40 & 0.60 \\
\hline \multicolumn{3}{|l|}{ Total soluble ions(1:5 Soil-water extractions) } \\
\hline \multicolumn{3}{|l|}{ Soluble cations } \\
\hline$m e q \mathrm{~L}^{-1}$ & 1.10 & 1.00 \\
\hline$m e q \mathrm{~L}^{-1}$ & 1.46 & 1.20 \\
\hline$m e q \mathrm{~L}^{-1}$ & 1.50 & 3.70 \\
\hline$m e q \mathrm{~L}^{-1}$ & 0.14 & 0.10 \\
\hline \multicolumn{3}{|l|}{ Soluble anions } \\
\hline$m e q \mathrm{~L}^{-1}$ & 0.00 & 0.00 \\
\hline$m e q \mathrm{~L}^{-1}$ & 2.30 & 1.50 \\
\hline$m e q \mathrm{~L}^{-1}$ & 1.40 & 2.00 \\
\hline$m e q L^{-1}$ & 0.30 & 2.50 \\
\hline (1:5 soil-water extraction) & 0.416 & 0.602 \\
\hline lonic strength (I.S) & 4.50 & 4.45 \\
\hline Sodium adsorption ratio(SAR) & 1.327 & 3.53 \\
\hline Soluble sodium percentage(SSP) & 35.71 & 61.7 \\
\hline \multicolumn{3}{|l|}{ Physical analysis } \\
\hline Particle size distribution & & \\
\hline Coarse sand fraction & 65.0 & 50.0 \\
\hline Fine sand fraction & 10.0 & 5.50 \\
\hline Silt fraction & 15.0 & 31.0 \\
\hline Clay fraction & 10.0 & 13.5 \\
\hline Soil texture class & Loamy sand & Loamy sand \\
\hline Soil bulk density(Db) & 1.57 & 1.55 \\
\hline Soil particle density (Dp) ) & 2.66 & 2.66 \\
\hline Total porosity(pt) on volume basis & 34.21 & 41.73 \\
\hline Soil saturated hydraulic conductivity (S.H.C) & 2.52 & 2.65 \\
\hline
\end{tabular}


El-Kammah,M.A.M. et al. 